\title{
1 A Prototype for Modular Cell Engineering
}

2

3 Brandon Wilbanks*, Donovan S. Layton*, Sergio Garcia and Cong T. Trinh ${ }^{\S}$

4 Department of Chemical and Biomolecular Engineering, University of Tennessee, Knoxville

5

$6 *$ contributed equally

7

$8 \quad{ }^{\S}$ Corresponding author. Email: ctrinh@utk.edu; Tel: 865-974-8121

9

10

11

12 


\section{ABSTRACT}

14 When aiming to produce a target chemical at high yield, titer, and productivity, various

15 combinations of genetic parts available to build the target pathway can generate a large number

16 of strains for characterization. This engineering approach will become increasingly laborious and

17 expensive when seeking to develop desirable strains for optimal production of a large space of

18 biochemicals due to extensive screening. Our recent theoretical development of modular cell

19 (MODCELL) design principles can offer a promising solution for rapid generation of optimal

20 strains by coupling a modular cell and exchangeable production modules in a plug-and-play

21 fashion. In this study, we experimentally validated some designed properties of MODCELL by

22 demonstrating: i) a modular (chassis) cell is required to couple with a production module, a

23 heterologous ethanol pathway, as a testbed, ii) degree of coupling between the modular cell and

24 production modules can be modulated to enhance growth and product synthesis, iii) a modular

25 cell can be used as a host to select an optimal pyruvate decarboxylase (PDC) of the ethanol

26 production module and to help identify a hypothetical PDC protein, and iv) adaptive laboratory

27 evolution based on growth selection of the modular cell can enhance growth and product

28 synthesis rates. We envision that the MODCELL design provides a powerful prototype for

29 modular cell engineering to rapidly create optimal strains for synthesis of a large space of

30 biochemicals.

32 Key words: Modular cell, MODCELL, growth selection, production module, growth coupling,

33 pyruvate decarboxylase, ethanol, adaptive laboratory evolution 


\section{INTRODUCTION}

Cellular metabolisms are diverse and complex, encompassing a substantial space of

37 chemicals ${ }^{1,2}$. Harnessing these cellular metabolisms for biocatalysis provides a promising path

38 to industrialization of biology that can potentially synthesize these chemicals from renewable

39 feedstocks and organic wastes ${ }^{3-5}$. To achieve this, it is necessary to rewire cellular metabolisms

to achieve production efficiency in a rapid and controllable fashion.

Metabolic engineering and synthetic biology are shaping industrialization of biology. A

42 variety of model-guided tools have been developed to enable rational strain engineering that

43 guide desirable genetic knock-outs, knock-ins, and up/down expression systems for redirecting

44 metabolic fluxes to desirable engineered pathways, with applications ranging from production of

45 industrially-relevant bulk chemicals to specialty products and drugs ${ }^{6-11}$. Synergistically,

46 synthetic biology has offered a wide range of genetic tools to engineer promoters ${ }^{12-14}$, ribosome

47 binding sites ${ }^{15}$, terminators ${ }^{16,17}$, plasmid copy numbers ${ }^{18,19}$, regulatory and sensory elements ${ }^{20-}$

$48^{22}$, and genetic circuits ${ }^{23,24}$ for controlling metabolic fluxes. With advancement in DNA

49 sequencing, gene synthesis, and pathway assembly, strain variants can be rapidly built and

50 subsequently tested for efficient chemical production ${ }^{22,25-28}$. The current limitation, however, is

51 to screen for a large space of strain variants through multiple design-build-test cycles of strain

52 optimization to achieve a desirable production phenotype ${ }^{5}$. When expanding to produce a large

53 space of desirable chemicals, the current strain engineering approach will become increasingly

54 laborious and expensive.

55 Modular design offers the most efficient route for rapid and systematic production that

56 has been applied in most aspects of our modern society, from constructing houses and buildings

57 to transportation systems, industrial factories, and intricate communication networks.

58 Remarkably, biological systems also follow modular design principles ${ }^{29-32}$, and exploiting these 
59 principles can potentially facilitate rapid and systematic generation of optimal strains to produce

60 a large space of biochemicals ${ }^{1,33}$, a promising path toward industrialization of biology. Recent

61 advances in metabolic engineering have significantly progressed to enable modular design of

62 synthetic pathways for combinational biosynthesis of chemicals and fuels ${ }^{3,34-39}$. However,

63 prototypes for modular cell engineering are still underdeveloped for generating the desirable

64 modular (chassis) cell that is most compatible with pathway modules to achieve most desirable

65 production phenotypes with minimal strain engineering efforts.

67 developed to enable modular cell engineering ${ }^{40}$. Based on the MODCELL design principles, a

68 production strain is assembled from a modular (chassis) cell and a production module. A

69 modular cell is designed to be auxotrophic, containing core metabolic pathways that are

70 necessary but insufficient to support cell growth and maintenance. To function, the modular cell

71 must couple with an exchangeable production module containing auxiliary pathways that can

72 complement cell growth and enhance production of targeted molecules. The stronger the

73 coupling between a modular cell and exchangeable production modules, the faster the coupled

74 cells grow, consume substrates, and efficiently produce target chemicals ${ }^{1}$. The production

75 modules are required to balance redox, energy, and intracellular metabolites for sustained

76 cellular metabolism during growth and/or stationary phases. Modular cells are designed to

77 rapidly create optimal production strains with minimal strain optimization cycles.

79 prototype for modular cell engineering. We show that a modular (chassis) cell is required to

80 couple with a production module, using a heterologous ethanol pathway, as a testbed. By varying

81 the strengths of production modules, we illustrate the degrees of coupling between the modular

82 cell and production modules can be modulated to enhance growth and product synthesis. We 
83 further demonstrate a modular cell can be used as a host to select an optimal pyruvate

84 decarboxylase (PDC) of the ethanol production module and to help identify a hypothetical PDC

85 protein. Lastly, we illustrate that adaptive laboratory evolution based on growth selection of the

86 modular cell can enhance growth and target product synthesis rates.

88 RESULTS AND DISCUSSION

89 Characterization of designed properties of a modular cell and production modules

To validate the MODELL design, we first constructed the modular cell TCS095 (DE3),

91 derived from TCS083 ${ }^{41}$, containing 10 genetic modifications including chromosomal disruption

92 of pta (encoding phosphate acetyl transferase), poxB (encoding pyruvate oxidase), ldhA

93 (encoding lactate dehydrogenase), $a d h E$ (encoding alcohol dehydrogenase), zwf (encoding

94 glucose-6-phosphate dehydrogenase), $n d h$ (encoding NADH:quinone oxidoreductase II), frdA

95 (encoding fumarate reductase), and $s f c A / m a e B$ (encoding malate enzyme) as well as

96 chromosomal integration of $\mathrm{T} 7$ polymerase gene. This modular cell is a prototype of

97 MODCELL1 that is designed to strongly couple with exchange production modules for

98 producing alcohols (ethanol, butanol, isobutanol) and esters (ethyl butyrate, isobutyl butyrate,

99 and butyl butyrate) ${ }^{40}$. Based on the MODCELL design ${ }^{40}$, the MODCELL1 is auxotrophic under

100 anaerobic conditions due to imbalance of redox and precursor metabolites required for cell

101 synthesis. To validate some properties of MODCELL, we focused on design, construction, and

102 characterization of the ethanol production modules (Figure 1).

We first built the ethanol module, pDL023, a two-operon, two-gene pathway, that is

104 comprised of a pyruvate decarboxylase gene $p d c_{\mathrm{ZM}}$, derived from Zymomonas mobilis, to convert

105 pyruvate to acetaldehyde and an alcohol dehydrogenase gene $a d h B_{\mathrm{ZM}}$ to convert acetaldehyde to 
106 ethanol. We also constructed the incomplete ethanol production modules only containing either

$107 p d c_{\mathrm{ZM}}(\mathrm{pCT} 15)$ or $a d h B_{\mathrm{ZM}}(\mathrm{pCT} 022)$. By transforming pCT15, pCT022, and pCT023 into

108 TCS095 (DE3), we generated the coupled cells EcDL107, EcDL108, and ECDL109,

109 respectively (Figure 2A).

110 Strain characterization shows that the engineered modular cell TCS095 (DE3) indeed

111 could not grow anaerobically while the coupled cell EcDL109 (carrying the complete ethanol

112 production module pDL023) could grow with a specific growth rate of $0.1838 \pm 0.0090(1 / \mathrm{h})$ and

113 reach a maximum optical density (OD, measured at $600 \mathrm{~nm}$ ) of $1.3927 \pm 0.0310$ (Figure 2B).

114 Furthermore, EcDL109 consumed all glucose within $24 \mathrm{~h}$ and mainly produced ethanol with a

115 yield of $0.4507 \pm 0.0038(\mathrm{~g} \mathrm{ETOH} / \mathrm{g} \mathrm{GLC})(>90 \%$ of the theoretical limit, $0.51 \mathrm{~g} \mathrm{ETOH} / \mathrm{g}$ GLC)

116 and a specific rate of $0.9131 \pm 0.0157(\mathrm{~g} \mathrm{ETOH} / \mathrm{g} \mathrm{DCW} / \mathrm{h})($ Figure $2 \mathrm{C})$. As a negative control,

117 the uncoupled cells that contained the incomplete ethanol production modules, EcDL107

118 (carrying pCT15) and EcDL108 (carrying pCT022), could not support cell growth (Figure 2B).

119 Infeasible growth of EcDL107 also implies that AdhB was mainly responsible for conversion of

120 acetaldehyde to ethanol since the native AdhE of the modular cell TCS095 (DE3) was disrupted.

121 Overall, these results validated the designed property that the modular cell is auxotrophic

122 due to imbalance of redox and precursor metabolites and requires strong coupling with a

123 production module for growth and efficient production of target chemicals. This strategy of

124 strong coupling has been previously shown for production of butanol ${ }^{42,}{ }^{43}$, isobutanol ${ }^{44}$,

125 succinate $^{45}$, short-chain esters ${ }^{3,4,34,35}$, isopentenol ${ }^{46}$, itaconic acid ${ }^{47}$ from glucose and ethanol

126 from glycerol ${ }^{48}$. Since synthesis and regulation of redox and precursor metabolites are linked

127 within cellular metabolism, any perturbation will affect redox state and precursor requirement for

128 cell growth and maintenance ${ }^{49}$. The redox imbalance resulting in auxotrophy in the modular cell

129 can be readily explained from the simplified metabolic network shown in Figure 1 . For the 
130 modular cell, the endogenous ethanol pathway is insufficient to maintain redox state because the

131 pathway requires two NADHs per $1 / 2$ glucose while the glycolysis only produces half of the

132 necessary cofactors. Also, strains carrying a deletion of the bifunctional aldehyde/alcohol

133 dehydrogenase AdhE of the ethanol pathway did not enable cellular growth due to

134 underutilization of the NADH cofactor generated from glycolysis. In essence, selection of

135 production modules by the modular cell works as antibiotics but links directly to desirable

136 production phenotypes.

138 Modulating degrees of coupling of modular cell and production modules to enhance cell

139 growth and product synthesis

140 To further demonstrate whether degrees of coupling of the modular cell and production

141 modules can be modulated to enhance cell growth and product formation, we constructed three

142 one-operon, two-gene ethanol modules, with tunable strengths by varying promoters. The

143 strongest module, pCT24, contained the strongest T7 promoter, whereas the weaker modules,

144 pAY1 and pAY3, carried the BBa_J23100 and BBa_J23108 promoters, derived from the iGEM

145 Andersen promoter library ${ }^{50}$, respectively. Among promoters in the library, BBa_J23100 was

146 reported to have the highest strength while BBa_J23108 has 51\% activity of BBa_J23100. Due

147 to differences in host strains and growth conditions, we have also independently checked and

148 confirmed the strengths of promoters used in our study: T7 >> BBa_J23100 $\geq$ BBa_J23108

149 (Supplementary Figure 1). We constructed three coupled cells, EcDL110, EcDL111, and

150 EcDL112, by transforming the modules pAY3, pAY1, and pCT24 and into the modular cell

151 TCS095 (DE3), respectively (Figure 3A).

152 Strain characterization shows that EcDL112, carrying the module pCT24 with the

153 strongest $\mathrm{T} 7$ promoter, achieved the highest growth rate of $0.1881 \pm 0.0079(1 / \mathrm{h})$, glucose 
154 consumption rate of $3.8216 \pm 0.8532(\mathrm{~g} \mathrm{GLC} / \mathrm{g} \mathrm{DCW} / \mathrm{h})$, and ethanol production rate of $1.4350 \pm$

$1550.4556(\mathrm{~g} \mathrm{ETOH} / \mathrm{g}$ DCW/h) (Figure 3B-3D). EcDL111, carrying the module pAY1 with the

156 second strongest promoter, yielded the second highest growth rate of $0.1494 \pm 0.0128(1 / \mathrm{h})$,

157 glucose consumption rate of $2.4799 \pm 0.1012(\mathrm{~g} \mathrm{GLC} / \mathrm{gDCW} / \mathrm{h})$, and ethanol production rate of

$1580.9176 \pm 0.1755(\mathrm{~g}$ ETOH/g DCW/h) (Figure 3B-3D). EcDL110, carrying the module pAY3

159 with the weakest promoter, obtained the lowest growth rate of $0.0855 \pm 0.0007(1 / \mathrm{h})$, glucose

160 consumption rate of $0.8599 \pm 0.2848(\mathrm{~g} \mathrm{GLC} / \mathrm{g} \mathrm{DCW} / \mathrm{h})$, and ethanol production rate of $0.3859 \pm$

$1610.0388(\mathrm{~g} \mathrm{ETOH} / \mathrm{g}$ DCW/h) (Figure 3B-D). Both EcDL112 and EcDL111 consumed all glucose

162 and reached maximum ODs of $1.8433 \pm 0.1361$ and $1.7500 \pm 0.0520$, respectively, within $30 \mathrm{~h}$

163 while EcDL110 did not. In addition, we also observed a strong linear correlation $\left(\mathrm{R}^{2}=0.98\right)$

164 between growth and ethanol production rates (Figure 3E).

165

Taken all together, these results demonstrate that the stronger the coupling between the

166 modular cell and ethanol production modules, the faster the coupled cells grew, consumed

167 glucose, and produced ethanol. Coupling was able to be controlled directly by modifying

168 metabolic fluxes through the pathway of interest. For developing prototypes for modular cell

169 engineering, stronger production modules with balanced fluxes should be enforced to create

170 desirable coupled cells for enhanced production of target chemicals. Production modules with

171 imbalanced fluxes of intermediate steps can significantly affect target product yields as observed

172 for production of isobutanol, ethyl butyrate, isopropyl butyrate, and isobutyl butyrate. $3,4,34,35,44$

\section{Enabling modular cells for enzyme selection}

175 Selection of PDCs with the modular cell TCS095 (DE3). Upon confirming the strong

176 coupling between the modular cell and ethanol production module, we next tested whether the 
177 modular cell TCS095 (DE3) can be used as a selection host for a target enzyme, i.e., a pyruvate

178 decarboxylase PDC of the ethanol production module. We selected five eukaryotic PDC genes,

179 including $p d c_{\mathrm{Sc} 1}, p d c_{\mathrm{Sc} 5}$, and $p d c_{\mathrm{Sc} 6}$ of $S$. cerevisiae, $p d c_{\mathrm{Ppa}}$ of $P$. pastoris, and putative $p d c_{\mathrm{Yli}}$ of

$180 Y$. lipolytica, that are divergently different from bacterial PDCs (e.g., $p d c_{\mathrm{ZM}}$ of $Z$. mobilis). It has

181 been reported that the in vitro catalytic efficiencies of $\mathrm{PDC}_{\mathrm{Sc} 1}, \mathrm{PDC}_{\mathrm{Sc} 5}, \mathrm{PDC}_{\mathrm{Sc} 6}$ and $\mathrm{PDC}_{\mathrm{Ppa}}$ are

182 relatively similar but significantly lower than that of the bacterial $\mathrm{PDC}_{\mathrm{ZM}}$ (Supplementary Figure

183 2) ${ }^{51}$. The activity of putative PDC $_{\text {Yli }}$ is widely unknown, which makes it a good candidate to test

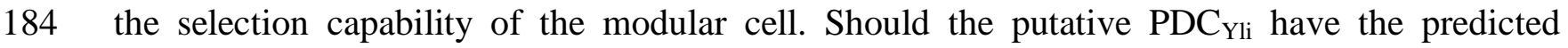

185 function, the coupled cell carrying the $\mathrm{PDC}_{\text {Yli-dependent ethanol module will grow and produce }}$

186 ethanol; the stronger the activity of $\mathrm{PDC}_{\mathrm{Yli}}$, the faster the coupled cell will grow and produce

187 ethanol.

We created a library of five two-operon, two-gene ethanol production modules in which

189 we varied the PDC genes and fixed a relatively strong $\mathrm{AdhB}_{\mathrm{ZM}}$ gene. The complete ethanol

190 production modules, including pDL024, pDL025, pDL026, pDL027, and pDL028, contained

$191 p d c_{\mathrm{Sc} 1}, p d c_{\mathrm{Sc} 5}, p d c_{\mathrm{Sc} 6}, p d c_{\mathrm{Ppa}}$ and $p d c_{\mathrm{Yli}}$, respectively, together with the common $a d h B_{Z M}$ gene. By

192 transforming these modules into the modular cell TCS095 (DE3), we constructed the coupled

193 cells EcDL118, EcDL119, EcDL120, EcDL121, and EcDL122, respectively (Figure 4A). For

194 negative controls, we also built the incomplete ethanol modules, including pCT15, pDL017,

195 pDL018, pDL019, pDL020, and pDL021, that contained only $p d c_{\mathrm{Zm}}, p d c_{\mathrm{Sc} 1}, p d c_{\mathrm{Sc} 5}, p d c_{\mathrm{Sc} 6}$,

$196 p d c_{\mathrm{Ppa}}$ and $p d c_{\mathrm{Yli}}$, respectively, without the $\mathrm{AdhB}_{\mathrm{ZM}}$ gene. The uncoupled cells carrying these

197 incomplete ethanol modules are EcDL107, EcDL113, EcDL114, EcDL115, EcDL116, and

198 EcDL117, respectively (Figure 4A).

199 Strain characterization shows that both the negative and positive controls were

200 confirmed. Specifically, the positive control strain EcDL109 grew (Figure 4C) while the negative 
control strains, including TCS095 (DE3), EcDL107, and EcDL113-EcDL117, could not (Figure 4B). For the test experiments, only the coupled cell EcDL121 containing PDC $_{\text {Ppa }}$ grew (Figure 4C). EcDL121 (0.0153 \pm 0.0003 1/h) grew much slower than EcDL109 (0.1838 \pm 0.0090 1/h) with lower glucose consumption rate $(0.5127 \pm 0.0097 \mathrm{~g} \mathrm{GLC} / \mathrm{g}$ DCW/h$)$ and ethanol production rate $(0.1327 \pm 0.0031 \mathrm{~g} \mathrm{ETOH} / \mathrm{g}$ DCW/h) (Figure 4D) mainly because EcDL121 carried a much weaker ethanol production module than EcDL109 (i.e., $\mathrm{PDC}_{\mathrm{ZM}}>>\mathrm{PDC}_{\mathrm{PPa}}$ ). Further, EcDL121 only grew up to a maximum OD of $0.4247 \pm 0.0297, \sim 3.3$ fold less than EcDL109, and did not completely consume glucose within $96 \mathrm{~h}$.

Even though some eukaryotic $\mathrm{PDC}_{\mathrm{Sc} 1}, \mathrm{PDC}_{\mathrm{Sc} 5}$, and $\mathrm{PDC}_{\mathrm{Sc} 6}$ were previously reported to have higher in vitro catalytic efficiencies than $\mathrm{PDC}_{\mathrm{Ppa}}{ }^{51}$, the coupled cells, EcDL118, EcDL119,

211 and EcDL120, containing these PDCs could not grow. These observed phenotypes could have

212 been caused by non-optimized translation of these eukaryotic PDC genes and/or inefficient in

213 vivo enzymatic activities in the heterologous host. As a result, the selection pressure by TCS095

214 (DE3) might have been too strong for the weak ethanol modules containing these eukaryotic

215 PDCs. The very weak coupling between the modular cell and the modules caused the imbalance

216 of redox and precursor metabolites (e.g., pyruvate, acetyl CoA) and hence inhibited growth of 217 some coupled cells carrying weak eukaryotic PDCs.

218 Selection of PDCs with the modular cell TCS083 (DE3). To be able to detect the in vivo 219 activities of $\mathrm{PDC}_{\mathrm{Sc} 1}, \mathrm{PDC}_{\mathrm{Sc} 5}, \mathrm{PDC}_{\mathrm{Sc} 6}$, and $\mathrm{PDC}_{\mathrm{Yll}}$, it is necessary to reduce the strength of 220 selection of TCS095 (DE3). Our strategy was to allow the native, bifunctional 221 acetaldehyde/ethanol dehydrogenase AdhE to relieve redox and/or acetylCoA imbalance that

222 eukaryotic PDCs of the weak ethanol modules alone could not overcome. Based on the 223 MODCELL design, TCS083 (DE3), which is the parent of the modular cell TCS095 (DE3) and 224 still possesses the native AdhE, can function as a modular cell ${ }^{40}$. By coupling TCS083 (DE3) 
with pDL024 (containing $\left.p d c_{\mathrm{Sc} 1} / a d h B_{\mathrm{Zm}}\right), \mathrm{pDL} 025\left(p d c_{\mathrm{Sc} 5} / a d h B_{\mathrm{Zm}}\right), \mathrm{pDL026}\left(p d c_{\mathrm{Sc} 6} / a d h B_{\mathrm{Zm}}\right)$,

$226 \mathrm{pDL} 027\left(p d c_{\mathrm{Ppa}} / a d h B_{\mathrm{Zm}}\right)$, and pDL028 ( $\left.p d c_{\mathrm{Yli}} / a d h B_{\mathrm{Zm}}\right)$, we constructed the coupled cells

227 EcDL123, EcDL124, EcDL125, EcDL126, and EcDL127, respectively (Figure 5A). The coupled

228 cell EcDL128 carrying pDL023 $\left(p d c_{\mathrm{Zm}} / a d h B_{\mathrm{Zm}}\right)$ was used as a positive control while the

229 modular cell TCS083 (DE3) was tested as a negative control.

230 Strain characterization shows that the coupled cell EcDL128, carrying pDL023

231 ( $p d c_{\mathrm{Zm}} / a d h B_{\mathrm{Zm}}$, positive control), could grow while the modular cell TCS083 (DE3) (negative

232 control) alone could not (Figure 5B). As expected, EcDL128, carrying the strongest PDC $\mathrm{Zm}_{\mathrm{m}}$

233 demonstrated the strongest product coupling among all strains tested with the highest growth rate

234 of $0.1753 \pm 0.0034(1 / \mathrm{h})$, glucose consumption rate of $2.4495 \pm 0.0662(\mathrm{~g} \mathrm{GLC} / \mathrm{g} \mathrm{DCW} / \mathrm{h})$, and

235 ethanol production rate of $1.0118 \pm 0.0577 \mathrm{~g} \mathrm{ETOH} / \mathrm{g} \mathrm{DCW} / \mathrm{h}$ (Figure 5B-5E). EcDL128

236 reached a maximum OD of $1.2167 \pm 0.0537$ and completely consumed glucose with an ethanol

237 yield of $\sim 90 \%$ theoretical maximum value (Figure 5). It is interesting to observe that the

238 performance of EcDL128 (derived from TCS083 (DE3)) is very similar to that of EcDL109

239 (derived from TCS095 (DE3)), which indicates that AdhB alone is sufficiently strong to support

240 the turnover of all necessary acetaldehyde in the designed ethanol production modules.

Using TCS083 (DE3) as the modular cell, all weakly-coupled cells were able to grow.

242 EcDL125, EcDL126, and EcDL127 grew at a similar rate of $\sim 0.05(1 / \mathrm{h})$, and faster than

$243 \operatorname{EcDL} 123(0.0434 \pm 0.00361 / \mathrm{h})$ and EcDL124 (0.0368 \pm 0.0033 1/h). As compared to EcDL128,

244 these strains grew $~ 3.4-4.8$ fold slower, did not completely consume glucose within $96 \mathrm{~h}$, and

245 reached lower maximum ODs of $\sim 0.34-0.56$, mainly due to weak ethanol production modules

246 (Figure 5B-5D). Similarly, all TCS083-derived, weakly-coupled cells yielded ethanol

247 production rates of $~ 2.3-6.4$ fold lower than the control EcDL128 $(1.0118 \pm 0.0577 \mathrm{~g} \mathrm{ETOH} / \mathrm{g}$

$248 \mathrm{DCW} / \mathrm{h})\left(\right.$ Figure 5E). We also observed a strong correlation $\left(\mathrm{R}^{2}=0.91\right)$ between specific growth 
rates and ethanol production rates of coupled cells carrying ethanol production modules derived

250 from different PDCs. Notably, Y. lipolytica PDC is demonstrated for the first time to have in vivo

251 activity as observed by ethanol production in EcDL127.

Native AdhE in the modular cell TCS083 (DE3) is sufficient to facilitate PDC

selection. We further examined whether the native AdhE alone in TCS083 (DE3) is sufficient for

254 the modular cell to select eukaryotic PDCs that are much weaker than $\mathrm{PDC}_{\mathrm{ZM}}$. We constructed

255 EcDL129, EcDL130, EcDL131, EcDL132, EcDL133, and EcDL134 by introducing pCT15

256 (containing $\left.p d c_{\mathrm{ZM}}\right), \mathrm{pDL017}\left(p d c_{\mathrm{Sc1}}\right), \mathrm{pDL018}\left(p d c_{\mathrm{Sc} 5}\right), \mathrm{pDL019}\left(p d c_{\mathrm{Sc} 6}\right), \mathrm{pDL020}\left(p d c_{\mathrm{Ppa}}\right)$, and

257 pDL021 ( $\left.p d c_{\text {Yli }}\right)$ in TCS083 (DE3), respectively (Supplementary Figure 3A). While the modular

258 cell TCS083 (DE3) (negative control) could not grow, all coupled cells could even without using

$259 \mathrm{AdhB}_{\mathrm{ZM}}$ (Supplementary Figure 3B). This result suggests that the endogenous AdhE was indeed

260 sufficient and required for the ethanol production module to couple with the module cell

261 TCS083.

262 EcDL129, carrying the strongest $\mathrm{PDC}_{\mathrm{ZM}}$, grew much faster than the weakly-coupled cells

263 carrying the eukaryotic PDCs by $~ 2.1-2.7$ folds. Interestingly, all weakly-coupled cells

264 EcDL130-EcDL134 exhibited very similar growth, glucose consumption, and ethanol production

265 rates like EcDL123-EcDL127 even though they only used native AdhE without AdhB ${ }_{\mathrm{ZM}}$

266 (Supplementary Figure 3C-3E). In contrast, EcDL129 underperformed EcDL128 when not using

$267 \mathrm{AdhB}_{\mathrm{ZM}}$. These results suggest that AdhE helped EcDL129-EcDL134 balance redox to support

268 cell growth. The AdhE flux (acetaldehyde $+\mathrm{NADH}+\mathrm{H}^{+} \rightarrow$ ethanol $+\mathrm{NAD}^{+}$), however, became

269 limiting in EcDL129 but not in EcDL130-134 because PDC $\mathrm{ZM}$ of EcDL129 is much stronger

270 than eukaryotic PDCs of EcDL130-EcDL134. Further, the results imply that eukaryotic PDCs

271 were limiting and the bifunctional acetaldehyde/alcohol dehydrogenase AdhE was critical for

272 selection of weak ethanol production modules. 
Taken all together, we validate the MODCELL design property that a modular cell can be

274 exploited for enzyme selection and discovery. Like modification of promoter strengths, varying

275 PDCs of the ethanol module provides an alternative method to adjust degrees of coupling

276 between the modular cell and production modules. These couplings can be clearly evidenced by

277 a strong linear correlation $\left(\mathrm{R}^{2}=0.96\right)$ between cell growth and ethanol production rates

278 (Supplementary Figure 4A). Manipulating these degrees of coupling also generated some

279 remarkable trends that can help establish a prototype for modular cell engineering.

280 The coupled cells exhibited optimal growth and ethanol production for a coupling either

281 between a strong modular cell (TCS095 (DE3)) and a strong ethanol module (pDL023 and

282 pCT24) or between a less strong modular cell (TCS083 (DE3)) and a strong ethanol module. In

283 contrast, the coupled cells exhibited significantly slow to no growth and reduced ethanol

284 production phenotypes for a coupling between a strong modular cell and a weak ethanol module

285 (pDL024 - pDL028). Growth and ethanol production were slightly improved for a coupling

286 between a less strong modular cell and a weak ethanol module (EcDL129 - EcDL134). These

287 results underline the importance of balancing push-and-pull carbon and electron fluxes. It is also

288 critical to utilize strong production modules for modular cell engineering to pull carbon and

289 electron fluxes from the core pathways of the modular cell to production modules.

291 Adaptive laboratory evolution of the coupled modular cells

\section{Evolution of weakly coupled cells resulted in enhanced growth and ethanol production}

293 rates. Due to the strong coupling between the modular cell and production modules, we

294 examined whether the adaptive laboratory evolution ${ }^{52,53}$ based on the growth selection of the

295 modular cell could enhance growth and ethanol production rates of the weakly-coupled cells

296 EcDL130 - EcDL134. We performed the evolution by continuously transferring cultures of 
297 EcDL130 - EcDL134 during logarithmic cell growth though serial dilution in two biological

298 replicates for $\sim 150$ generations ( 45 transfers) (Figure 6A). For dilutions 12 ( 35 generations),

29920 ( 60 generations), and 40 (135 generations), we also performed the extensive irreversibility

300 testing by isolating individual colonies of coupled cells and characterizing their performances for

301 cell growth and ethanol production.

302

The results show that the evolved EcDL130e - EcDL134e significantly improved growth

303

and ethanol production rates during the adaptive laboratory evolution (Figure 6B-6D). It should

304 be noted that the letter "e" following EcDL130 - EcDL134 signifies that these strains

305 EcDL130e-EcDL134e undergo an adaptive laboratory evolution; and when a number appears

306 after "e", it represents the number of dilution. For instance, EcDL130e40 is an evolved strain

307 isolated at the dilution 40. For comparison and discussion hereafter, we used the performance of

$308 \operatorname{EcDL129}\left(\mu=0.1021 \pm 0.00591 / \mathrm{h}\right.$ and $\left.\mathrm{r}_{\mathrm{P}}=0.4819 \pm 0.0368 \mathrm{~g} \mathrm{ETOH} / \mathrm{g} \mathrm{DCW} / \mathrm{h}\right)$ as a

309 benchmark because it accomplished the highest growth and ethanol production rates of all six

310 PDCs tested before the evolution.

313 reached or surpassed the growth of EcDL129. Specifically, EcDL132e12 grew fastest with a

314 growth rate of $\sim 1.9$ folds higher than the benchmark strain EcDL129. After dilution 20, all cells

315 almost doubled the growth rate of the benchmark strain EcDL129 where specific growth rates of

316 EcDL130e20, EcDL131e20, EcDL132e20, EcDL133e20, and EcDL134e20 were 2.0, 1.9, 1.9,

3171.6 and 2.2 folds higher than that of EcDL129, respectively. After dilution 20, coupled cells

318 EcDL130e40-EcDL134e40 slightly improved growth where growth rates mostly reached

319 plateau at dilution 40, 2.0-2.6 folds higher than EcDL129. Single colony isolates at dilutions 
12, 20, and 40 were also characterized for irreversibility test, and all matched the observed,

321 enhanced growth phenotypes of evolved cultures (Supplementary Figure 5). Throughout dilution,

322 evolved cells enhanced not only growth but also glucose consumption and ethanol production

323 rates (Supplementary Figure 6). At dilution 40, coupled cells EcDL130e40, EcDL131e40,

324 EcDL132e40, EcDL133e40, and EcDL134e40 reached the ethanol production rates 3.0, 2.5,

$3254.0,2.8$, and 2.3 folds higher than their parents, respectively. All coupled cells either matched or

326 slightly surpassed the ethanol production rate of EcDL129. Interestingly, we observed that there

327 exists a weak correlation between growth and ethanol production rates for EcDL130-134 and

328 their evolved derivatives at dilutions 12, 20, and 40 (Supplementary Figure 4B).

whether the host or production modules contributed to enhanced phenotypes of evolved mutants,

331 we isolated and characterized both. To characterize the evolved ethanol production modules, we

332 selected three representative evolved cells EcDL130e40 (with PDC $_{\text {Sc1), EcDL133e40 (with }}$

333 PDC $_{\mathrm{Ppa}}$ ), and EcDL134e40 (with $\mathrm{PDC}_{\mathrm{Yli}}$ ), extracted their plasmids, transformed them back to the

334 unevolved parent modular cell TCS083 (DE3), and characterized. The results show that these

335 coupled cells did not improve growth rates as compared to their parents (Supplementary Figure

336 7).

340 hence used it for characterization. We transformed the original modules pCT15, pDL017,

341 pDL018, pDL019, pDL020, and pDL021 into TCS083e40 for characterization. Most coupled

342 cells were able to regain the enhanced growth phenotypes of the evolved mutants (Figure 7A).

343 Interestingly, TCS083e40 pCT15 doubled the growth rate of EcDL129 (TCS083 pCT15) (Figure 
344 7B). In addition to improved growth, we also observed increase in ethanol production rates of the

345 coupled cells derived from the evolved modular cell TCS083e40 and the original ethanol

346 production modules (Figure 7C).

347 Taken all together, these results demonstrate that the modular cell can be used a selection

348 host for adaptive laboratory evolution to enhance growth and production synthesis rates of

349 coupled cells. The evolved EcDL130e-EcDL134e might have acquired beneficial mutations on

350 core metabolisms of the modular cell to achieve higher growth and ethanol production rates but

351 probably not on the production modules. Future studies will investigate the beneficial mutations

352 through OMICS analysis and genome resequencing. Our results concur with previous studies of

353 plasmid-bacteria evolution that plasmids tend to resist mutations even undergoing long-term

354 (>500 generations) adaptive laboratory evolution experiments ${ }^{54,55}$. Based on this observation, to

355 acquire beneficial mutations on the production modules, it might be necessary to generate in

356 vitro module variants (e.g., protein mutagenesis ${ }^{56}$ ) and use the modular cell for selection.

We have developed a prototype for modular cell engineering based on the MODCELL

360 design principles. Using a heterologous ethanol pathway as a testbed, we characterized and

361 validated some designed properties of a modular cell. We demonstrated the auxotrophy of two

362 modular cell designs by coupling them with no module or any incomplete module. By

363 modulating the degrees of coupling with various promoter strengths or activities of PDCs of

364 ethanol production modules, we demonstrated that the strong coupling is critical for enhanced

365 growth and product formation. This strong coupling enabled the modular cell to be used as a host

366 to select an optimal pyruvate decarboxylase (PDC) of the ethanol production module or discover 
367 function of the hypothetical PDC protein from $Y$. lipolytica. Using the modular cell platform,

368 adaptive laboratory evolution based on growth selection provides a simple but powerful

369 technique to enhance growth and product rates of a targeted pathway. We envision that

370 MODCELL provides a powerful prototype of modular engineering to rapidly create optimal

371 strains for efficient production of a large space of biochemicals and help minimize the design-

372 build-test cycles of strain engineering.

374 METHODS

\section{Strains}

376 Table 1 lists strains used in this study. E. coli TOP10 was used for molecular cloning.

377 TCS095 was constructed from TCS083 ${ }^{41}$ by deleting chromosomal gene adhE using P1

378 transduction ${ }^{57}$. The prophage $\lambda \mathrm{DE} 3$ was used to insert a T7 polymerase gene into the specific

379 site of TCS083 or TCS095 by using a commercial kit for strains expressing a T7 promoter

380 (cat\#69734-3, Novagen Inc.). TCS083 ( $\lambda$ DE3), TCS095 ( $\lambda$ DE3), and their derivatives carrying

381 production modules were used for modular cell engineering and characterization (Table 1). All

382 mutants and plasmids were PCR confirmed with the primers used listed in Supplementary Table 3831.

\section{Plasmid/pathway construction}

Construction of PDC modules. The pETite*, a vector backbone ${ }^{34}$, was used to construct

387 PDC modules - containing PDC genes derived from Z. mobilis, S. cerevisiae, P. pastoris, and $Y$.

388 lipolytica under T7 promoters - using the Gibson gene assembly method ${ }^{58}$. To construct the

389 modules pDL017, pDL018, and pDL019, the genes PDC1 ${ }_{\mathrm{Sc}}, \mathrm{PDC}_{\mathrm{Sc}}$, and PDC6 ${ }_{\mathrm{Sc}}$ were 
amplified from S. cerevisiae cDNA using the primers DL_0036/ DL_0037, DL_0038/ DL_0039, and DL_0040/ DL_0041, respectively, and then inserted into the pETite* backbone isolated by using the primers DL_0001/DL_0002. Likewise, the $\mathrm{PDC}_{\mathrm{Ppa}}$ gene was amplified from $P$. pastoris cDNA using the primers DL_0042/ DL_0043 and inserted into the pETite* backbone, generating the module pDL020. The module pDL021 was constructed by amplifying the PDC $\mathrm{Yli}_{\mathrm{i}}$ gene from $Y$. lipolytica cDNA using the primers DL_0044/ DL_0045 and inserted into the pETite* backbone.

The Z. mobilis $\mathrm{PDC}_{\mathrm{ZM}}$ gene was assembled into the pETite* vector to create the module pCT15 by using the BglBrick gene assembly ${ }^{59}$ of 2 DNA pieces: i) PDC ZM $_{\text {gene amplified using }}$ genomic DNA of Z. mobilis using the primers P006_f/P006_r and digested with NdeI/BamHI and ii) the vector backbone pETite* doubly digested with NdeI/BamHI.

Construction of AdhB modules. The AdhB module pDL022 was generated by amplifying $\mathrm{AdhB}_{\mathrm{Zm}}$ from pCT24 using primers DL_0046/ DL_0047 and inserted into the pETite* backbone using Gibson assembly. ethanol module pCT24 was previously constructed ${ }^{60}$. Briefly, pCT24 contains the Z. mobilis ethanol pathway encompassing PDC and AdhB genes. The variant PDC/AdhB ethanol modules

407 pAY1 and pAY3 were constructed from pCT24 by swapping the T7 promoter with two weaker 408 constitutive promoters ${ }^{50}$. The module pAY1 contains the BBa_J23100 promoter that was 409 constructed by amplifying pCT24 using the primers AY6.R/AY.7F, digested with BglII, and 410 ligated together. Likewise, the module pAY3 carries the BBa_J23108 promoter that was 411 constructed using the primers AY6.R/AY10.F, digested with BglII and ligated together.

412 In addition, we have constructed and characterized the two-operon, PDC/AdhB modules: 413 the first operon carrying a PDC gene derived from various species and the second operon 
414 containing the $\mathrm{adhB}_{\mathrm{Zm}}$ gene. The two-operon ethanol modules were constructed using the Gibson

415 assembly method using two parts: i) the PDC containing-plasmids pDL017-pDL021, pCT15

416 amplified using primers DL_0013/DL_0014 and ii) the adhB operon from pDL022 using primers

417 DL_0015/DL_0016 to generate pDL023-pDL028, respectively.

419 Medium and cell culturing

420 Culture media. For molecular cloning, the lysogeny broth (LB) medium, containing 10

$421 \mathrm{~g} / \mathrm{L}$ yeast extract, $5 \mathrm{~g} / \mathrm{L}$ tryptone, and $5 \mathrm{~g} / \mathrm{L} \mathrm{NaCl}$, was used. Antibiotics at working 422 concentrations of $50 \mu \mathrm{g} / \mathrm{mL}$ kanamycin (kan) was used, where applicable, to maintain the 423 selection of desired plasmids. For growth coupling experiments, the M9 (pH 7) medium was 424 used, consisting of $100 \mathrm{~mL} / \mathrm{L}$ of $10 X \mathrm{M} 9$ salts, $1 \mathrm{ml} / \mathrm{L}$ of $1 \mathrm{M} \mathrm{MgSO}_{4}, 100 \mu \mathrm{L} / \mathrm{L}$ of $1 \mathrm{M} \mathrm{CaCl}_{2}, 1$ $425 \mathrm{ml} / \mathrm{L}$ of stock thiamine $\mathrm{HCl}$ solution $(1 \mathrm{~g} / \mathrm{L}), 1 \mathrm{ml} / \mathrm{L}$ of stock trace metals solution ${ }^{41}$, and 426 appropriate antibiotics. Unless specified, $10 \mathrm{~g} / \mathrm{L}$ glucose was used in the M9 medium. The stock 427 10X M9 salt solution contained $67.8 \mathrm{~g} / \mathrm{L} \mathrm{Na}_{2} \mathrm{HPO}_{4}, 30 \mathrm{~g} / \mathrm{L} \mathrm{KH}_{2} \mathrm{PO}_{4}, 5 \mathrm{~g} / \mathrm{L} \mathrm{NaCl}$, and $10 \mathrm{~g} / \mathrm{L}$ $428 \mathrm{NH}_{4} \mathrm{Cl}$.

429 Strain characterization. Strain characterization experiments were performed by growing 430 cells overnight at $37^{\circ} \mathrm{C}$ in $15 \mathrm{~mL}$ culture tubes containing $\mathrm{LB}$ and appropriate antibiotics, then 431 subculturing into fresh M9 medium to adapt the cells to a defined environment. Cells were then 432 grown until exponential phase $\left(\mathrm{OD}_{600 \mathrm{~nm}} \sim 1.0,1 \mathrm{OD} \sim 0.5 \mathrm{~g} \mathrm{DCW} / \mathrm{L}\right)$. Next, cells (except the 433 modular strain TCS083 DE3) were again subcultured into a nitrogen sparged and pressured tube 434 to create a complete anaerobic environment to an initial $\mathrm{OD}_{600 \mathrm{~nm}} \sim 0.10-0.20$ at a working volume 435 of $20 \mathrm{~mL}$. The strains were allowed to adapt (at least 2 doublings) overnight to the anaerobic 436 environment and then transferred into pre-warmed $20 \mathrm{~mL}$ tubes dispersed of oxygen containing 437 M9 and appropriate antibiotics for characterization with an initial $\mathrm{OD}_{600 \mathrm{~nm}}$ of $\sim 0.030$. 
$439175 \mathrm{rpm}$. Whole-cells and cell supernatants were collected and stored at $-20^{\circ} \mathrm{C}$ for subsequent

440 metabolite analysis. All experiments were performed with at least three biological replicates.

441 Adaptive laboratory evolution. Strain evolution experiments were prepared and grown in

442 an identical way to the method described above for strain characterization experiments. Samples

443 for metabolite analysis were also taken in a similar manner as described in the strain

444 characterization method. Upon preparation of adapted anaerobic strains, cultures were grown in

445 duplicate from $\mathrm{OD}_{600}$ of $\sim 0.050$ until exponential phase was reached $\left(\mathrm{OD}_{600}\right.$ of $\left.0.5-1.0\right)$. A 1.5

$446 \mathrm{~mL}$ sample of each replicate was collected for stock. Each replicate was then diluted to $\mathrm{OD}_{600} \sim$

4470.05 and grown again to an $\mathrm{OD}_{600}$ of $0.5-1.0$, where samples were collected as before. This

448 process was repeated until a consistent maximum growth rate was reached. Evolution was then

449 tested for irreversibility.

450 When the consistent maximum growth rate was reached, cells were plated on LB plates

451 with antibiotic as needed. A single colony was selected and streaked out on a new plate and

452 repeated 3 times in order to ensure a single cell colony was isolated. Isolated evolved colonies

453 were tested for irreversibility. Cells were first grown and stocked at $-80^{\circ} \mathrm{C}$ before conducting the

454 experiment to allow for complete metabolic interruption and recovery. Irreversibility of the

455 adapted host strain and adapted plasmid were carried out in the same fashion as before in the

456 strain characterization method. Plasmids were extracted from the isolated colonies and

457 transformation into the unevolved parent strain (TCS083 DE3) for plasmid irreversibility test.

458 The evolved plasmid in the unevolved host was also characterized in the same method of the

459 strain coupling studies. 
463 Thermo Scientific Genysys 30 Visible Spectrophotometer with a proper adapter to measure

464 growth kinetics directly.

465 High performance liquid chromatography (HPLC). Extracellular metabolites were 466 quantified by first filtering cell supernatants though $0.2-\mu \mathrm{m}$ filter units and then analyzed using 467 the Shimadzu HPLC system equipped with RID and UV-Vis detectors (Shimadzu Inc., 468 Columbia, MD, USA) and Aminex HPX-87H cation exchange column (BioRad Inc., Hercules, 469 CA, USA). Samples were eluded though the column set at $50^{\circ} \mathrm{C}$ with a flow rate of $0.6 \mathrm{~mL} / \mathrm{min}$ 470 using the $10 \mathrm{mN} \mathrm{H}_{2} \mathrm{SO}_{4}$ mobile phase ${ }^{44}$.

472 Data analysis

474 from kinetic measurement of cell growth as follows:

$$
\mu=\frac{1}{\mathrm{C}_{X}} \cdot \frac{\mathrm{dC}_{X}}{\mathrm{dt}}
$$

where $\mu(1 / h)$ is the specific growth rate, $C_{X}(g / L)$ is cell titer, and $t(h)$ is culturing time.

478 follows:

$$
\mathrm{Y}_{\mathrm{S}_{\mathrm{i}} / \mathrm{S}_{\mathrm{j}}}=\frac{\mathrm{dC}_{\mathrm{Si}}}{\mathrm{dC}_{\mathrm{Sj}}}
$$

where $\mathrm{C}_{\mathrm{Si}}$ and $\mathrm{C}_{\mathrm{Sj}}(\mathrm{g} / \mathrm{L})$ are concentrations of $\mathrm{S}_{\mathrm{i}}$ and $\mathrm{S}_{\mathrm{j}}$, respectively.

$$
r_{S_{i}}=\mu \cdot Y_{S_{i} / X}=\mu \frac{d C_{S i}}{d C_{X}}
$$

Growth generation. The number of growth generation (n) is determined as follows: 


$$
\mathrm{n}=\log _{2} \frac{\mathrm{c}_{\mathrm{X}}\left(\mathrm{t}_{2}\right)}{\mathrm{C}_{\mathrm{X}}\left(\mathrm{t}_{1}\right)}
$$

\section{FUNDING}

488 This research was financially supported by the NSF CAREER award (NSF\#1553250).

\section{ACKNOWLEDGEMENTS}

491 We thank Akshitha Yarrabothula, Nirayan Niraula, and Katherine Krouse for helping with 492 molecular cloning and growth study experiments.

\section{AUTHOR CONTRIBUTIONS}

495 CTT perceived and supervised the study. CTT, DL, BW designed experiments. DL, BW, SG

496 performed the experiments. CTT, DL, BW analyzed the data. CTT wrote the manuscript. 


\section{REFERENCES}

1. Trinh, C. T., and Mendoza, B. (2016) Modular cell design for rapid, efficient strain engineering toward industrialization of biology, Current Opinion in Chemical Engineering 14, 18-25.

2. Council, N. R. (2015) Industrialization of biology: a roadmap to accelerate the advanced manufacturing of chemicals, National Academies Press.

3. Layton, D. S., and Trinh, C. T. (2016) Expanding the modular ester fermentative pathways for combinatorial biosynthesis of esters from volatile organic acids, Biotechnology and bioengineering.

4. Layton, D. S., and Trinh, C. T. (2016) Microbial synthesis of a branched-chain ester platform from organic waste carboxylates, Metabolic Engineering Communications 3, 245-251.

5. Nielsen, J., and Keasling, J. D. (2016) Engineering cellular metabolism, Cell 164, 1185-1197.

6. von Kamp, A., and Klamt, S. (2017) Growth-coupled overproduction is feasible for almost all metabolites in five major production organisms, Nature Communications 8.

7. Flowers, D., Thompson, R. A., Birdwell, D., Wang, T., and Trinh, C. T. (2013) SMET: systematic multiple enzyme targeting-a method to rationally design optimal strains for target chemical overproduction, Biotechnology Journal 8, 605-618.

8. Machado, D., and Herrgård, M. (2015) Co-evolution of strain design methods based on flux balance and elementary mode analysis, Metabolic Engineering Communications.

9. Chen, P.-W., Theisen, M. K., and Liao, J. C. (2017) Metabolic systems modeling for cell factories improvement, Current Opinion in Biotechnology 46, 114-119.

10. Ng, C. Y., Khodayari, A., Chowdhury, A., and Maranas, C. D. (2015) Advances in de novo strain design using integrated systems and synthetic biology tools, Current opinion in chemical biology 28, 105-114.

11. Chowdhury, A., and Maranas, C. D. (2015) Designing overall stoichiometric conversions and intervening metabolic reactions, Scientific reports 5.

12. Cox, R. S., 3rd, Surette, M. G., and Elowitz, M. B. (2007) Programming gene expression with combinatorial promoters, Mol Syst Biol 3, 145.

13. Mutalik, V. K., Guimaraes, J. C., Cambray, G., Lam, C., Christoffersen, M. J., Mai, Q. A., Tran, A. B., Paull, M., Keasling, J. D., Arkin, A. P., and Endy, D. (2013) Precise and reliable gene expression via standard transcription and translation initiation elements, Nat Methods 10, 354-360.

14. Redden, H., and Alper, H. S. (2015) The development and characterization of synthetic minimal yeast promoters, Nature communications 6 .

15. Salis, H. M., Mirsky, E. A., and Voigt, C. A. (2009) Automated design of synthetic ribosome binding sites to control protein expression, Nat Biotech 27, 946-950.

16. Chen, Y.-J., Liu, P., Nielsen, A. A., Brophy, J. A., Clancy, K., Peterson, T., and Voigt, C. A. (2013) Characterization of 582 natural and synthetic terminators and quantification of their design constraints, Nature methods 10, 659-664.

17. Cambray, G., Guimaraes, J. C., Mutalik, V. K., Lam, C., Mai, Q.-A., Thimmaiah, T., Carothers, J. M., Arkin, A. P., and Endy, D. (2013) Measurement and modeling of intrinsic transcription terminators, Nucleic acids research 41, 5139-5148.

18. Seo, J. H., and Bailey, J. E. (1985) Effects of recombinant plasmid content on growth properties and cloned gene product formation in Escherichia coli, Biotechnology and Bioengineering 27, 1668-1674. 
19. Karim, A. S., Curran, K. A., and Alper, H. S. (2013) Characterization of plasmid burden and copy number in Saccharomyces cerevisiae for optimization of metabolic engineering applications, FEMS yeast research 13, 107-116.

20. Taylor, N. D., Garruss, A. S., Moretti, R., Chan, S., Arbing, M. A., Cascio, D., Rogers, J. K., Isaacs, F. J., Kosuri, S., Baker, D., Fields, S., Church, G. M., and Raman, S. (2016) Engineering an allosteric transcription factor to respond to new ligands, Nat Meth 13, 177-183.

21. Zhang, F., Carothers, J. M., and Keasling, J. D. (2012) Design of a dynamic sensor-regulator system for production of chemicals and fuels derived from fatty acids, Nat Biotech 30, 354-359.

22. Jones, J. A., Vernacchio, V. R., Lachance, D. M., Lebovich, M., Fu, L., Shirke, A. N., Schultz, V. L., Cress, B., Linhardt, R. J., and Koffas, M. A. (2015) ePathOptimize: A Combinatorial Approach for Transcriptional Balancing of Metabolic Pathways, Sci Rep $5,11301$.

23. Nielsen, A. A., Der, B. S., Shin, J., Vaidyanathan, P., Paralanov, V., Strychalski, E. A., Ross, D., Densmore, D., and Voigt, C. A. (2016) Genetic circuit design automation, Science 352 , aac7341.

24. Callura, J. M., Cantor, C. R., and Collins, J. J. (2012) Genetic switchboard for synthetic biology applications, Proceedings of the National Academy of Sciences 109, 5850-5855.

25. Li, Y., Gu, Q., Lin, Z., Wang, Z., Chen, T., and Zhao, X. (2013) Multiplex iterative plasmid engineering for combinatorial optimization of metabolic pathways and diversification of protein coding sequences, ACS Synth Biol 2, 651-661.

26. Schaerli, Y., and Isalan, M. (2013) Building synthetic gene circuits from combinatorial libraries: screening and selection strategies, Mol Biosyst 9, 1559-1567.

27. Smanski, M. J., Bhatia, S., Zhao, D., Park, Y., L, B. A. W., Giannoukos, G., Ciulla, D., Busby, M., Calderon, J., Nicol, R., Gordon, D. B., Densmore, D., and Voigt, C. A. (2014) Functional optimization of gene clusters by combinatorial design and assembly, Nat Biotechnol 32, 1241-1249.

28. Freestone, T. S., and Zhao, H. (2016) Combinatorial pathway engineering for optimized production of the anti-malarial FR900098, Biotechnology and Bioengineering 113, 384392.

29. Ravasz, E., Somera, A. L., Mongru, D. A., Oltvai, Z. N., and Barabási, A.-L. (2002) Hierarchical organization of modularity in metabolic networks, science 297, 1551-1555.

30. Barabasi, A.-L., and Oltvai, Z. N. (2004) Network biology: understanding the cell's functional organization, Nature reviews genetics 5, 101-113.

31. Han, J.-D. J., Bertin, N., Hao, T., Goldberg, D. S., Berriz, G. F., Zhang, L. V., Dupuy, D., Walhout, A. J., Cusick, M. E., and Roth, F. P. (2004) Evidence for dynamically organized modularity in the yeast protein-protein interaction network, Nature 430, 88-93.

32. Newman, M. E. (2006) Modularity and community structure in networks, Proceedings of the national academy of sciences 103, 8577-8582.

33. Vickers, C. E., Blank, L. M., and Krömer, J. O. (2010) Grand challenge commentary: Chassis cells for industrial biochemical production, Nature chemical biology 6, 875.

34. Layton, D. S., and Trinh, C. T. (2014) Engineering modular ester fermentative pathways in Escherichia coli, Metabolic engineering 26, 77-88.

35. Wierzbicki, M., Niraula, N., Yarrabothula, A., Layton, D. S., and Trinh, C. T. (2016) Engineering an Escherichia coli platform to synthesize designer biodiesels, Journal of biotechnology 224, 27-34. 
36. Ajikumar, P. K., Xiao, W.-H., Tyo, K. E. J., Wang, Y., Simeon, F., Leonard, E., Mucha, O., Phon, T. H., Pfeifer, B., and Stephanopoulos, G. (2010) Isoprenoid Pathway Optimization for Taxol Precursor Overproduction in Escherichia coli, Science 330, 70-74.

37. Tseng, H.-C., and Prather, K. L. (2012) Controlled biosynthesis of odd-chain fuels and chemicals via engineered modular metabolic pathways, Proceedings of the National Academy of Sciences 109, 17925-17930.

38. Dellomonaco, C., Clomburg, J. M., Miller, E. N., and Gonzalez, R. (2011) Engineered reversal of the $\beta$-oxidation cycle for the synthesis of fuels and chemicals, Nature 476, 355-359.

39. Cheong, S., Clomburg, J. M., and Gonzalez, R. (2016) Energy-and carbon-efficient synthesis of functionalized small molecules in bacteria using non-decarboxylative Claisen condensation reactions, Nature Biotechnology.

40. Trinh, C. T., Liu, Y., and Conner, D. J. (2015) Rational design of efficient modular cells, Metabolic engineering 32, 220-231.

41. Trinh, C. T., Unrean, P., and Srienc, F. (2008) Minimal Escherichia coli cell for the most efficient production of ethanol from hexoses and pentoses, Applied and Environmental Microbiology 74, 3634-3643.

42. Trinh, C. T. (2012) Elucidating and reprogramming Escherichia coli metabolisms for obligate anaerobic n-butanol and isobutanol production, Applied Microbiology and Biotechnology, 1-12.

43. Shen, C. R., Lan, E. I., Dekishima, Y., Baez, A., Cho, K. M., and Liao, J. C. (2011) Driving forces enable high-titer anaerobic 1-butanol synthesis in Escherichia coli, Applied and environmental microbiology 77, 2905-2915.

44. Trinh, C. T., Li, J., Blanch, H. W., and Clark, D. S. (2011) Redesigning Escherichia coli metabolism for anaerobic production of isobutanol, Applied and environmental microbiology 77, 4894-4904.

45. Zhang, X., Jantama, K., Moore, J. C., Jarboe, L. R., Shanmugam, K. T., and Ingram, L. O. (2009) Metabolic evolution of energy-conserving pathways for succinate production in Escherichia coli, Proceedings of the National Academy of Sciences 106, 20180-20185.

46. Kang, A., Meadows, C. W., Canu, N., Keasling, J. D., and Lee, T. S. (2017) High-throughput enzyme screening platform for the IPP-bypass mevalonate pathway for isopentenol production, Metabolic Engineering 41, 125-134.

47. Harder, B.-J., Bettenbrock, K., and Klamt, S. (2016) Model-based metabolic engineering enables high yield itaconic acid production by Escherichia coli, Metabolic engineering 38, 29-37.

48. Trinh, C. T., and Srienc, F. (2009) Metabolic engineering of Escherichia coli for efficient conversion of glycerol to ethanol, Applied and Environmental Microbiology 75, 66966705.

49. Neidhardt, F. C., Ingraham, J. L., and Schaechter, M. (1990) Physiology of the bacterial cell : a molecular approach, Sinauer Associates, Sunderland, Mass.

50. Kelly, J. R., Rubin, A. J., Davis, J. H., Ajo-Franklin, C. M., Cumbers, J., Czar, M. J., de Mora, K., Glieberman, A. L., Monie, D. D., and Endy, D. (2009) Measuring the activity of BioBrick promoters using an in vivo reference standard, J Biol Eng 3, 4.

51. Agarwal, P. K., Uppada, V., and Noronha, S. B. (2013) Comparison of pyruvate decarboxylases from Saccharomyces cerevisiae and Komagataella pastoris (Pichia pastoris), Applied microbiology and biotechnology 97, 9439-9449. 
52. Conrad, T. M., Lewis, N. E., and Palsson, B. Ø. (2011) Microbial laboratory evolution in the era of genome-scale science, Molecular systems biology 7, 509.

53. Dragosits, M., and Mattanovich, D. (2013) Adaptive laboratory evolution-principles and applications for biotechnology, Microbial cell factories 12, 64. plasmid in different hosts: no guarantee for a long-term relationship, Microbiology 153, 452-463.

55. Bouma, J. E., and Lenski, R. E. (1988) Evolution of a bacteria/plasmid association, Nature $335,351-352$.

56. Higgins, S. A., Ouonkap, S. V. Y., and Savage, D. F. (2017) Rapid and Programmable Protein Mutagenesis Using Plasmid Recombineering, ACS Synthetic Biology.

57. Trinh, C. T., Carlson, R., Wlaschin, A., and Srienc, F. (2006) Design, construction and performance of the most efficient biomass producing E. coli bacterium, Metabolic engineering 8, 628-638.

58. Gibson, D., Young, L., Chuang, R., Venter, J., Hutchison, C., and Smith, H. (2009) Enzymatic assembly of DNA molecules up to several hundred kilobases, Nat Methods 6, $343-345$.

59. Anderson, J. C., Dueber, J. E., Leguia, M., Wu, G. C., Goler, J. A., Arkin, A. P., and Keasling, J. D. (2010) BglBricks: A flexible standard for biological part assembly, J Biol Eng 4, 1 .

60. Layton, D. S., Trinh, C.T. (2014) Engineering Modular Ester Fermentative Pathways in Escherichia coli, Metab Eng. 26, 77-88. 
660 Table 1. A list of strains and plasmids used in this study

\begin{tabular}{|c|c|c|}
\hline Plasmids/Strains & Genotypes & Sources \\
\hline \multicolumn{3}{|l|}{ Plasmids } \\
\hline pETite* & $\operatorname{kan}^{\mathrm{R}}$ & 60 \\
\hline pCT15 & $\mathrm{pETite}^{*} \mathrm{P}_{\mathrm{T} 7}:: \mathrm{RBS}:: p d c_{\mathrm{Zm}}:: \mathrm{T}_{\mathrm{T} 7} ; \mathrm{kan}^{+}$ & this study \\
\hline pDL017 & pETite $^{*} \mathrm{P}_{\mathrm{T} 7}:: \mathrm{RBS}:: p d c 1_{\mathrm{Sc}}:: \mathrm{T}_{\mathrm{T} 7} ; \mathrm{kan}^{+}$ & this study \\
\hline pDL018 & pETite $* \mathrm{P}_{\mathrm{T} 7}:: \mathrm{RBS}:: p d c 5_{\mathrm{Sc}}:: \mathrm{T}_{\mathrm{T} 7} ; \mathrm{kan}^{+}$ & this study \\
\hline pDL019 & pETite $* \mathrm{P}_{\mathrm{T} 7}:: \mathrm{RBS}:: p d c 6_{\mathrm{Sc}}:: \mathrm{T}_{\mathrm{T} 7} ; \mathrm{kan}^{+}$ & this study \\
\hline pDL020 & pETite $* \mathrm{P}_{\mathrm{T} 7}:: \mathrm{RBS}:: p d c_{\mathrm{Ppa}}:: \mathrm{T}_{\mathrm{T} 7} ; \mathrm{kan}^{+}$ & this study \\
\hline pDL021 & pETite* $\mathrm{P}_{\mathrm{T} 7}:: \mathrm{RBS}:: p d c_{\mathrm{Yli}}:: \mathrm{T}_{\mathrm{T} 7} ; \mathrm{kan}^{+}$ & this study \\
\hline pDL022 & pETite* $\mathrm{P}_{\mathrm{T} 7}:: \mathrm{RBS}:: a d h B_{\mathrm{Zm}}:: \mathrm{T}_{\mathrm{T} 7} ; \mathrm{kan}^{+}$ & this study \\
\hline pDL023 & $\begin{array}{l}\mathrm{pETite}^{*} \\
\mathrm{~T}_{\mathrm{T} 7} ; \mathrm{kan}^{+}\end{array} \quad \mathrm{P}_{\mathrm{T} 7}:: \mathrm{RBS}:: p d c_{\mathrm{Zm}}:: \mathrm{T}_{\mathrm{T} 7}:: \mathrm{P}_{\mathrm{T} 7}:: \mathrm{RBS}:: a d h B_{\mathrm{Zm}}::$ & this study \\
\hline pDL024 & $\begin{array}{l}\mathrm{pETite}^{*} \\
\mathrm{~T}_{\mathrm{T} 7} ; \text { kan }^{+}\end{array} \quad \mathrm{P}_{\mathrm{T} 7}:: \mathrm{RBS}:: p d c_{\mathrm{Sc} 1}:: \mathrm{T}_{\mathrm{T} 7}:: \mathrm{P}_{\mathrm{T} 7}:: \mathrm{RBS}:: a d h B_{\mathrm{Zm}}::$ & this study \\
\hline pDL025 & $\begin{array}{l}\mathrm{pETite}^{*} \\
\mathrm{~T}_{\mathrm{T} 7} ; \mathrm{kan}^{+}\end{array} \quad \mathrm{P}_{\mathrm{T} 7}:: \mathrm{RBS}:: p d c_{\mathrm{Sc} 5}:: \mathrm{T}_{\mathrm{T} 7}:: \mathrm{P}_{\mathrm{T} 7}:: \mathrm{RBS}:: a d h B_{\mathrm{Zm}}::$ & this study \\
\hline pDL026 & $\begin{array}{l}\mathrm{pETite}^{*} \\
\mathrm{~T}_{\mathrm{T} 7} ; \text { kan }^{+}\end{array} \quad \mathrm{P}_{\mathrm{T} 7}:: \mathrm{RBS}:: p d c_{\mathrm{Sc} 6}:: \mathrm{T}_{\mathrm{T} 7}:: \mathrm{P}_{\mathrm{T} 7}:: \mathrm{RBS}:: a d h B_{\mathrm{Zm}}::$ & this study \\
\hline pDL027 & $\begin{array}{l}\mathrm{pETite}^{*} \\
\mathrm{~T}_{\mathrm{T} 7} ; \mathrm{kan}^{+}\end{array} \quad \mathrm{P}_{\mathrm{T} 7}:: \mathrm{RBS}:: p d c_{\mathrm{Ppa}}:: \mathrm{T}_{\mathrm{T} 7}:: \mathrm{P}_{\mathrm{T} 7}:: \mathrm{RBS}:: a d h B_{\mathrm{Zm}}::$ & this study \\
\hline pDL028 & $\begin{array}{l}\mathrm{pETite}^{*} \\
\mathrm{~T}_{\mathrm{T} 7} ; \mathrm{kan}^{+}\end{array} \quad \mathrm{P}_{\mathrm{T} 7}:: \mathrm{RBS}:: p d c_{\mathrm{Yli}}:: \mathrm{T}_{\mathrm{T} 7}:: \mathrm{P}_{\mathrm{T} 7}:: \mathrm{RBS}:: a d h B_{\mathrm{Zm}}::$ & this study \\
\hline pCT24 & pETite* $\mathrm{P}_{\mathrm{T} 7}:: \mathrm{RBS}:: p d c:: \mathrm{RBS}:: a d h B:: \mathrm{T}_{\mathrm{T} 7} ; \mathrm{kan}^{+}$ & 60 \\
\hline pAY1 & pETite* $\mathrm{P}_{\mathrm{BBa} \_\mathrm{J} 23100}:: \mathrm{RBS}:: p d c:: \mathrm{RBS}:: a d h B:: \mathrm{T}_{\mathrm{T} 7} ; \mathrm{kan}^{+}$ & this study \\
\hline pAY3 & pETite* $\mathrm{P}_{\mathrm{BBa} \_} \mathrm{J} 23108:: \mathrm{RBS}:: p d c:: \mathrm{RBS}:: a d h B:: \mathrm{T}_{\mathrm{T} 7} ; \mathrm{kan}^{+}$ & this study \\
\hline \multicolumn{3}{|l|}{ Strains } \\
\hline S. cerevisiae & MAT a, ura3d0, his3-d200, leu2-d0, met15-d0 & ATCC 201388 \\
\hline P. pastoris & Wildtype & ATCC 28485 \\
\hline Y. lipolytica & $\begin{array}{l}\text { MATA ura3-302 leu2-270 xpr2-322 axp2- } \Delta \text { NU49 } \\
\text { XPR2::SUC2 }\end{array}$ & $\begin{array}{l}\text { ATCC MYA- } \\
2613\end{array}$ \\
\hline TOP10 & $\begin{array}{l}\text { F-mcrA } \Delta(\text { mrr-hsd } \mathrm{RMS}-\text { mcrBC }) \Phi 80 l a c \mathrm{Z} \quad \Delta \mathrm{M} 15 \\
\Delta l a c \mathrm{X} 74 \text { recA1 araD139 } \Delta(\text { ara leu }) 7697 \text { galU galK } \\
\operatorname{rpsL}(\mathrm{StrR}) \text { endA1 nupG }\end{array}$ & Invitrogen \\
\hline TCS083 & $\begin{array}{l}\text { MG1655, } l d h A:: \Delta f r d A:: \Delta s f c A:: \Delta m a e B:: \Delta z w f:: \Delta n d h:: \\
\Delta p t a:: \triangle p o x B\end{array}$ & 41 \\
\hline TCS083 (DE3) & $\begin{array}{l}\text { MG1655, } \triangle l d h A:: \Delta f r d A:: \Delta s f c A:: \Delta m a e B:: \Delta z w f:: \Delta n d h:: \\
\Delta p t a:: \triangle p o x B(\lambda D E 3)\end{array}$ & this study \\
\hline TCS095 (DE3) & $\begin{array}{l}\text { MG1655, } \operatorname{ldhA}:: \Delta f r d A:: \Delta s f c A:: \Delta m a e B:: \Delta z w f:: \Delta n d h:: \\
\Delta p t a:: \triangle p o x B:: \Delta a d h E(\lambda D E 3)\end{array}$ & this study \\
\hline EcDL107 & TCS095 (DE3) pCT15 (pdc Zm $) ; \mathrm{kan}^{+}$ & this study \\
\hline EcDL108 & TCS095 (DE3) pCT15 (adhB $\mathrm{Zm}) ; \mathrm{kan}^{+}$ & this study \\
\hline EcDL109 & TCS095 (DE3) pDL022 (pdc $\left.c_{\mathrm{Zm}} a d h B_{\mathrm{Zm}}\right) ; \mathrm{kan}^{+}$ & this study \\
\hline EcDL110 & TCS095 (DE3) pDL023 (pAY3); kan ${ }^{+}$ & this study \\
\hline
\end{tabular}




\begin{tabular}{|c|c|c|}
\hline EcDL111 & TCS095 (DE3) pAY1; kan ${ }^{+}$ & this study \\
\hline EcDL112 & TCS095 (DE3) pCT24; kan ${ }^{+}$ & this study \\
\hline EcDL113 & TCS095 (DE3) pDL017 $\left(p d c_{\mathrm{Sc} 1}\right) ; \mathrm{kan}^{+}$ & this study \\
\hline EcDL114 & TCS095 (DE3) pDL018 $\left(p d c_{\mathrm{Sc} 5}\right) ; \mathrm{kan}^{+}$ & this study \\
\hline EcDL115 & TCS095 (DE3) pDL019 ( $\left.p d c_{\mathrm{Sc} 6}\right) ; \mathrm{kan}^{+}$ & this study \\
\hline EcDL116 & TCS095 (DE3) pDL020 ( $\left.p d c_{\mathrm{Ppa}}\right) ; \mathrm{kan}^{+}$ & this study \\
\hline EcDL117 & TCS095 (DE3) pDL021 ( $\left.p d c_{\text {Yli }}\right) ; \mathrm{kan}^{+}$ & this study \\
\hline EcDL118 & TCS095 (DE3) pDL023 ( $\left.p d c_{\mathrm{Sc} 1} a d h B_{\mathrm{Zm}}\right) ; \mathrm{kan}^{+}$ & this study \\
\hline EcDL119 & TCS095 (DE3) pDL024 (pdc $\left.c_{\mathrm{Sc} 5} a d h B_{\mathrm{Zm}}\right) ; \mathrm{kan}^{+}$ & this study \\
\hline EcDL120 & TCS095 (DE3) pDL025 (pdc $\left.c_{\mathrm{Sc} 6} a d h B_{\mathrm{Zm}}\right) ; \mathrm{kan}^{+}$ & this study \\
\hline EcDL121 & TCS095 (DE3) pDL026 ( $\left.p d c_{\mathrm{Ppa}} a d h B_{\mathrm{Zm}}\right) ; \mathrm{kan}^{+}$ & this study \\
\hline EcDL122 & TCS095 (DE3) pDL027 ( $\left.p d c_{\text {Yli }} a d h B_{\mathrm{Zm}}\right) ; \mathrm{kan}^{+}$ & this study \\
\hline EcDL123 & TCS083 (DE3) pDL023 (pdc $\left.c_{\mathrm{Sc} 1} a d h B_{\mathrm{Zm}}\right) ; \mathrm{kan}^{+}$ & this study \\
\hline EcDL124 & TCS083 (DE3) pDL024 (pdc $\left.c_{\mathrm{Sc} 5} a d h B_{\mathrm{Zm}}\right) ; \mathrm{kan}^{+}$ & this study \\
\hline EcDL125 & TCS083 (DE3) pDL025 (pdc $\left.c_{\mathrm{Sc} 6} a d h B_{\mathrm{Zm}}\right) ; \mathrm{kan}^{+}$ & this study \\
\hline EcDL126 & TCS083 (DE3) pDL026 ( $\left.p d c_{\mathrm{Ppa}} a d h B_{\mathrm{Zm}}\right) ; \mathrm{kan}^{+}$ & this study \\
\hline EcDL127 & TCS083 (DE3) pDL027 ( $\left.p d c_{\text {Yli }} a d h B_{\mathrm{Zm}}\right) ; \mathrm{kan}^{+}$ & this study \\
\hline EcDL128 & TCS083 (DE3) pDL028 (pdc $\left.c_{\mathrm{Zm}} a d h B_{\mathrm{Zm}}\right) ; \mathrm{kan}^{+}$ & this study \\
\hline EcDL129 & TCS083 (DE3) pCT15 (pdc Zm $) ; \mathrm{kan}^{+}$ & this study \\
\hline EcDL130 & TCS083 (DE3) pDL017 $\left(p d c_{\mathrm{Sc} 1}\right) ; \mathrm{kan}^{+}$ & this study \\
\hline EcDL131 & TCS083 (DE3) pDL018 ( $\left.p d c_{\mathrm{Sc} 5}\right) ; \mathrm{kan}^{+}$ & this study \\
\hline EcDL132 & TCS083 (DE3) pDL019 $\left(p d c_{\mathrm{Sc} 6}\right) ; \mathrm{kan}^{+}$ & this study \\
\hline EcDL133 & TCS083 (DE3) pDL020 ( $\left.p d c_{\mathrm{Ppa}}\right) ; \mathrm{kan}^{+}$ & this study \\
\hline EcDL134 & TCS083 (DE3) pDL021 ( $\left.p d c_{\text {Yli }}\right) ; \mathrm{kan}^{+}$ & this study \\
\hline
\end{tabular}




\section{FIGURE LEGENDS}

666 Figure 1. Homoethanol pathways for modular cell growth selection. The pathway highlighted in

667 green is heterologous and redox-balanced that can couple with the modular cell, TCS095 (DE3)

668 or TCS083 (DE3), to enable cell growth under anaerobic conditions. The pathway highlighted in

669 gray is native but redox-unbalanced, which does not enable growth under anaerobic conditions

670 using the modular cell.

671

672 Figure 2. Strong coupling between the modular cell TCS095 (DE3) and ethanol production 673 modules. (A) Coupled cells EcDL107, EcDL108, and EcDL109 assembled by the modular cell

674 TCS095 (DE3) and ethanol production modules. (B) Cell growth. (C) Ethanol production and 675 glucose consumption profiles of EcDL109. The modular cell TCS095 (DE3) and uncoupled 676 cells, EcDL107 and EcDL108, containing incomplete ethanol modules (negative control) while 677 EcDL109 carries a complete two-operon, two-gene ethanol module (test).

679 Figure 3. Modulation of degrees of coupling between the modular cell TCS095 (DE3) and 680 ethanol production modules. (A) Coupled cells EcDL110, EcDL111, and EcDL112 assembled

681 from the modular cell TCS095 (DE3) and the one-operon, two-gene ethanol production modules, 682 pCT24, pAY1, and pAY3, using promoters of different strengths. (B) Cell growth. (C) Glucose 683 consumption. (D) Ethanol production. (E) Correlation of growth and ethanol production rates.

685 Figure 4. Selection and discovery of pyruvate decarboxylases by the modular cell TCS095 686 (DE3). (A) Uncoupled cells EcDL113-EcDL117 and coupled cells EcDL118-EcDL122 
687 assembled from the modular cell TCS095 (DE3) with incomplete and complete ethanol

688 production modules, respectively. (B) Cell growth of the modular cell TCS095 (DE3) and

689 uncoupled cells EcDL113-EcDL117 carrying incomplete ethanol modules only carrying PDCs

690 (negative controls). (C) Cell growth of weakly-coupled cells EcDL118-EcDL122 that carry

691 complete ethanol modules with various PDCs. (D) Ethanol production and glucose consumption

692 profiles of EcDL109 and EcDL121.

693

694 Figure 5. Selection and discovery of pyruvate decarboxylases by the modular cell TCS083

695 (DE3). (A) Coupled cells EcDL123-EcDL128 assembled from the modular cell TCS083 (DE3)

696 with the two-operon, two-gene ethanol modules. (B) Cell growth. (C) Glucose consumption. (D)

697 Ethanol production. (E) Correlation of growth and ethanol production rates.

699 Figure 6. Metabolic pathway evolution enhanced growth and ethanol production rates of 700 weakly-coupled cells. (A) Metabolic pathway evolution carried out by the serial culture dilution.

701 Individual evolved cells can be isolated by serial plate spreading. Characterization of growth and

702 ethanol production rates during the metabolic pathway evolution of weakly coupled cells

703 including (A) EcDL130, (B) EcDL131, (C) EcDL132, (D) EcDL133, and (E) EcDL134 for a

704 period of 150 generations. In panels B-F, the ethanol production rates were evaluated from 705 individual isolates from dilutions 12, 20, and 40.

707 Figure 7. Adapted modular cells contributed to enhanced phenotypes of evolved cells. (A)

708 Growth kinetics of the coupled cells assembled from the adapted modular cell carrying the parent 709 ethanol modules including pCT15, pDL017, pDL018, pDL019, pDL020, and pDL021. The 710 evolved modular cell TCS083e30 was isolated from EcDL133e40 at dilution 40 after rejecting 
bioRxiv preprint doi: https://doi.org/10.1101/170910; this version posted July 31, 2017. The copyright holder for this preprint (which was not certified by peer review) is the author/funder, who has granted bioRxiv a license to display the preprint in perpetuity. It is made available under aCC-BY-NC-ND 4.0 International license.

711 pDL020. Comparison of (B) growth rate and (C) ethanol production rate among the parent

712 coupled cells, evolved cells, and adapted modular cell carrying the parent ethanol production

713 modules. 
bioRxiv preprint doi: https://doi.org/10 1101/170910; this version posted July 31 2017. The copyright holder for this preprint (which was not certified by peer review) is the author/funder, who has granted bioRxiv a license to display the preprint in perpetuity. It is made available under aCC-BY-NC-ND 4.0 International license.

\section{FIGURE 1}

715

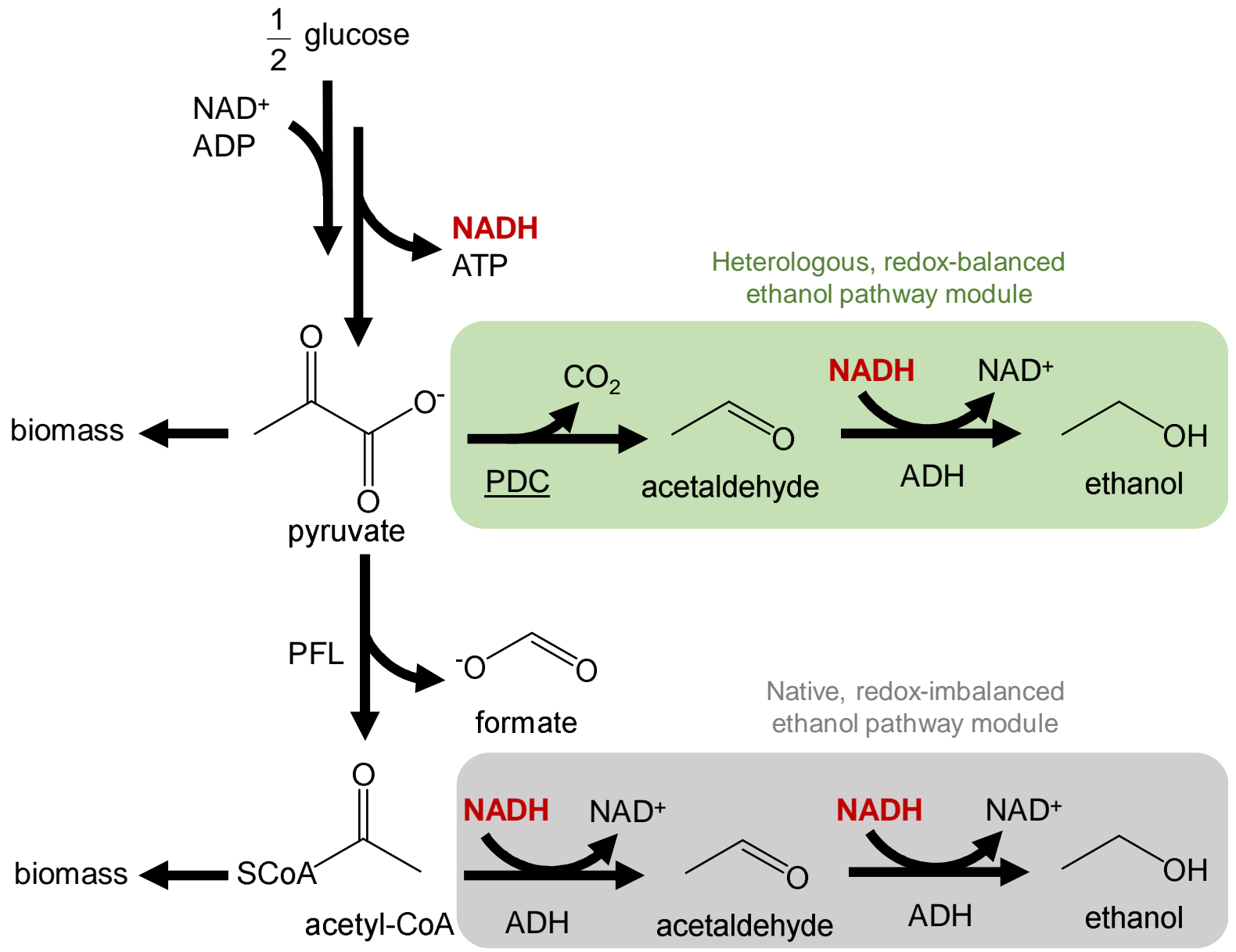


bioRxiv preprint doi: https://doi.org/10.1101/170910 this version posted July 31 2017. The copyright holder for this preprint (which was not certified by peer review) is the author/funder, who has granted bioRxiv a license to display the preprint in perpetuity. It is made available under aCC-BY-NC-ND 4.0 International license.

\section{FIGURE 2}

A

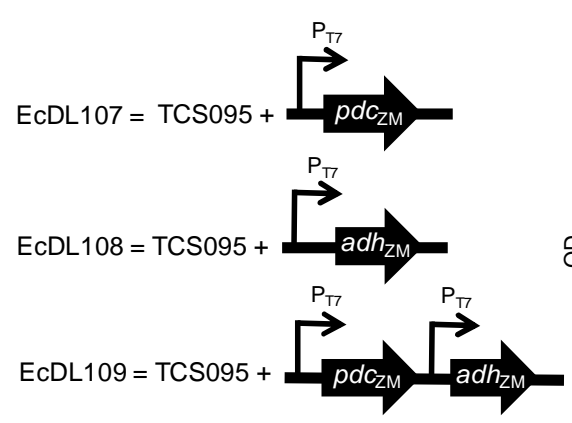

B

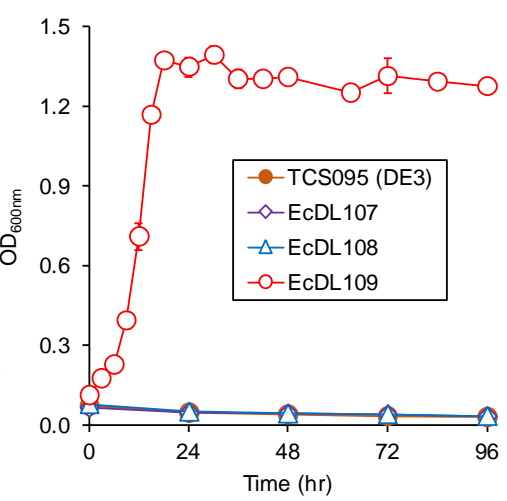

C

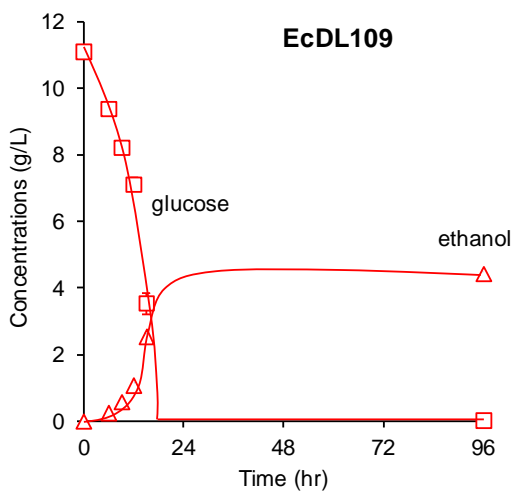

721

722

723

724

725 
bioRxiv preprint doi: https://doi.org/10.1101/170910; this version posted July 31, 2017. The copyright holder for this preprint (which was not certified by peer review) is the author/funder, who has granted bioRxiv a license to display the preprint in perpetuity. It is made available under aCC-BY-NC-ND 4.0 International license.

\section{FIFURE 3}

A
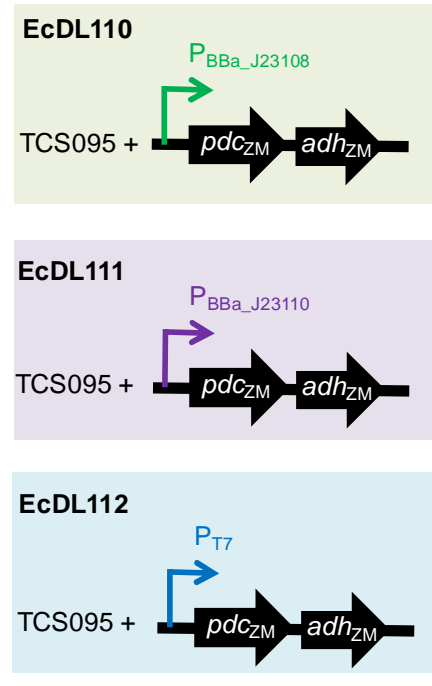

B

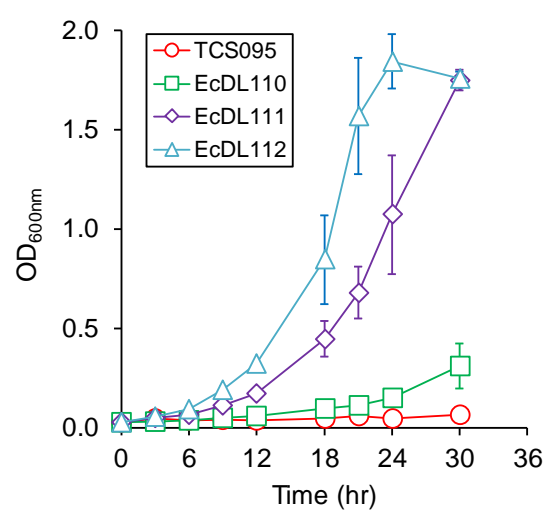

D

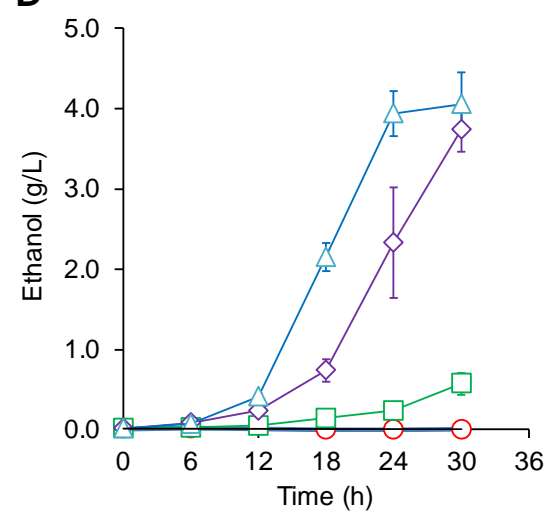

C

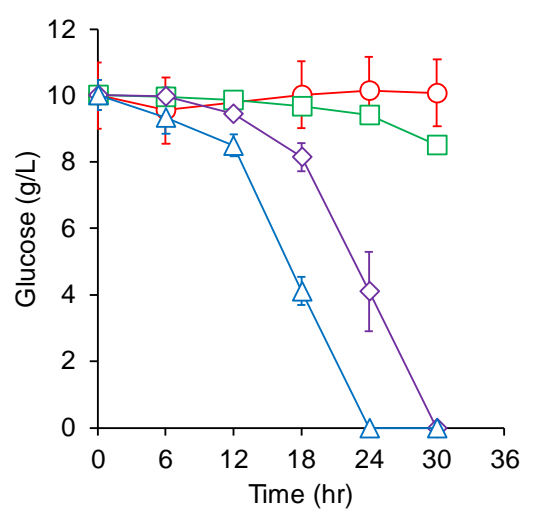

E

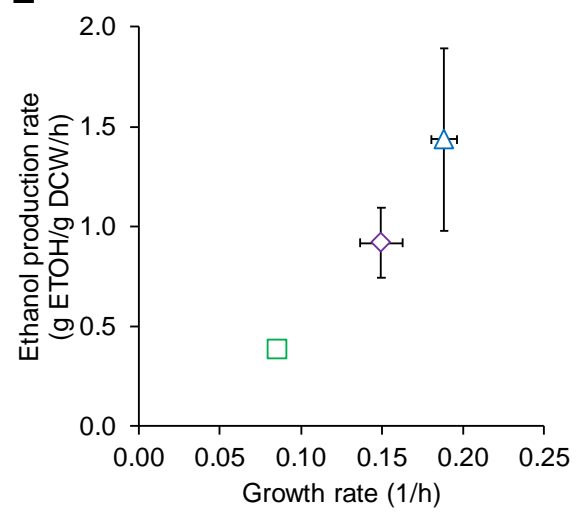


bioRxiv preprint doi: https://doi org/10.1101/170910 this version posted July 31,2017. The copyright holder for this preprint (which was not certified by peer review) is the author/funder, who has granted bioRxiv a license to display the preprint in perpetuity. It is made available under aCC-BY-NC-ND 4.0 International license.

FIGURE 4

\section{1}

A
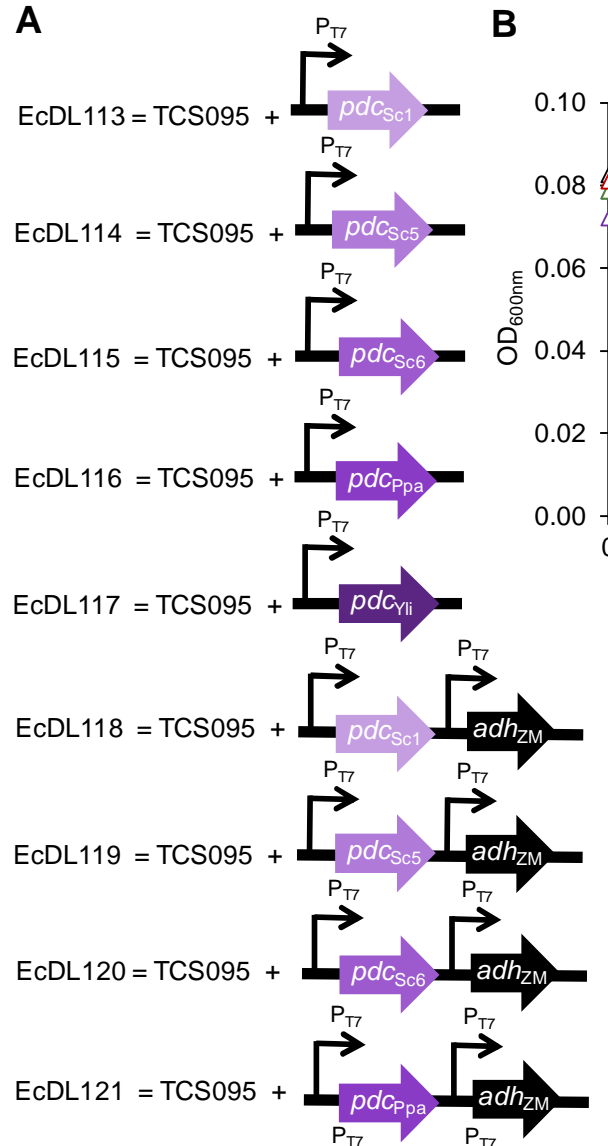

732

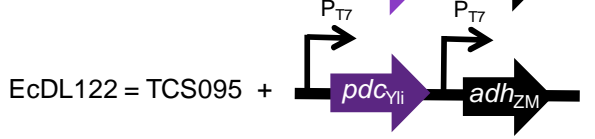

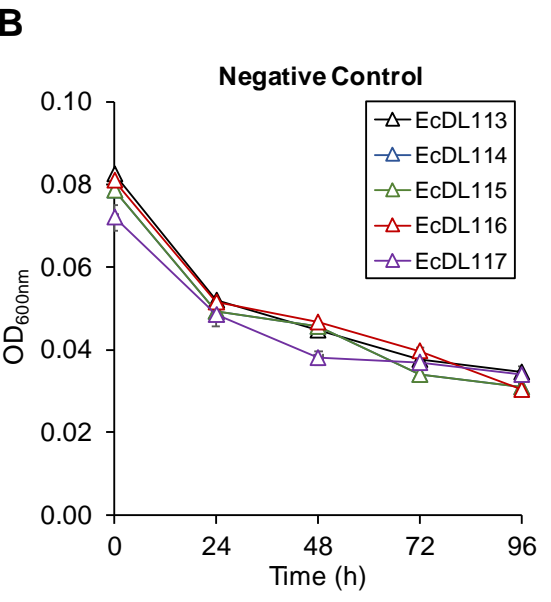

C

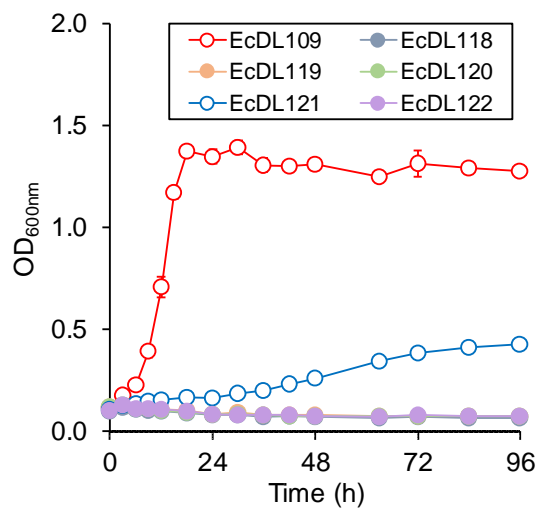

D

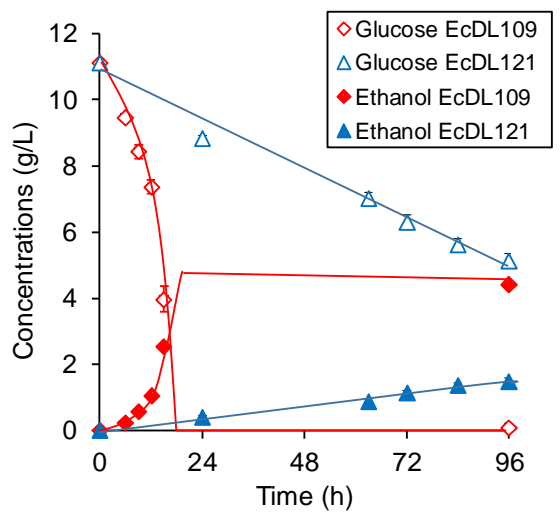

733 
bioRxiv preprint doi: https://doi.org/10.1101/170910 this version posted July 31,2017. The copyright holder for this preprint (which was not certified by peer review) is the author/funder, who has granted bioRxiv a license to display the preprint in perpetuity. It is made available under aCC-BY-NC-ND 4.0 International license.

FIGURE 5

A
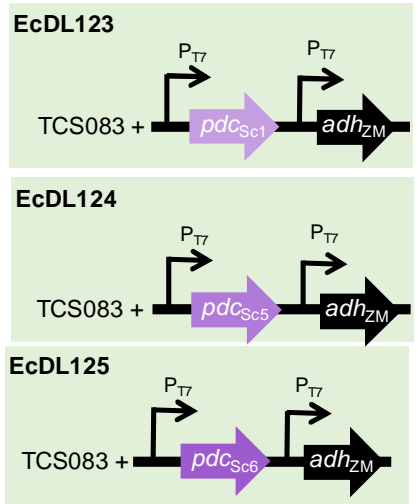

C

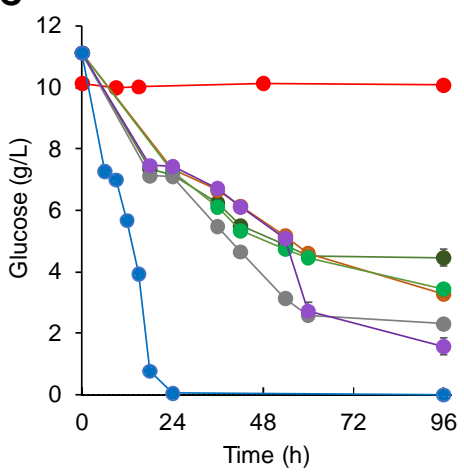

B

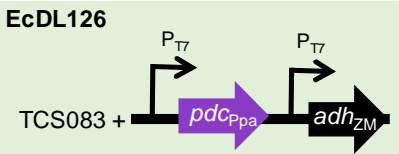

EcDL127

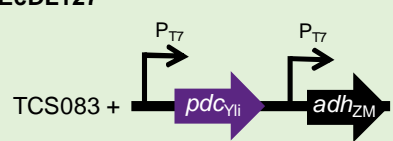

EcDL128

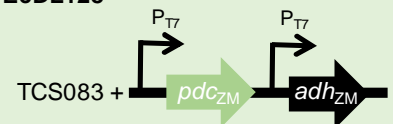

D

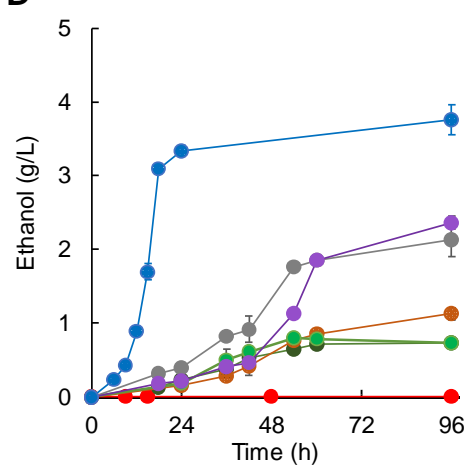

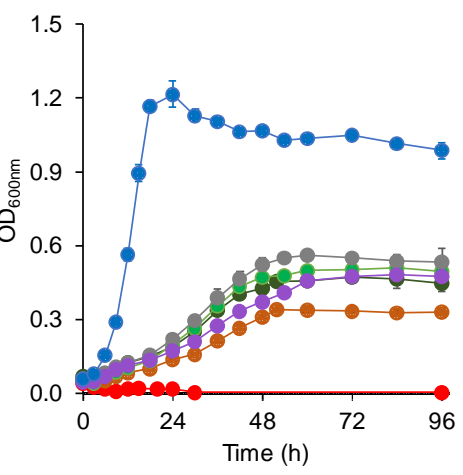

E

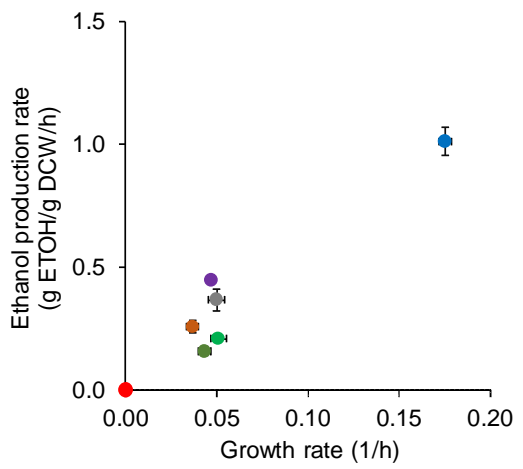


bioRxiv preprint doi: https://doi.org/10.1101/170910 this version posted July 31, 2017. The copyright holder for this preprint (which was not certified by peer review) is the author/funder, who has granted bioRxiv a license to display the preprint in perpetuity. It is made available under aCC-BY-NC-ND 4.0 International license.

A

Metabolic pathway evolution

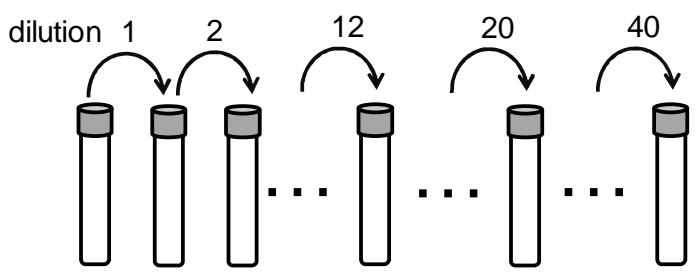

B

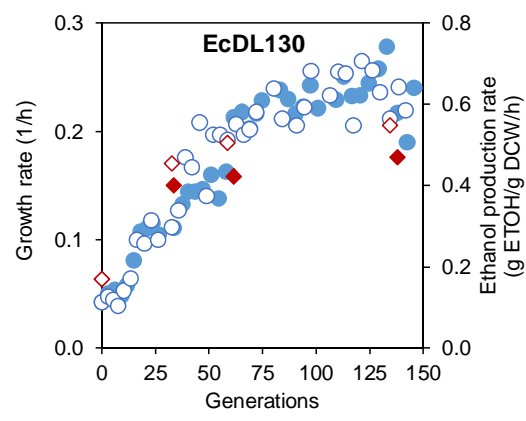

E

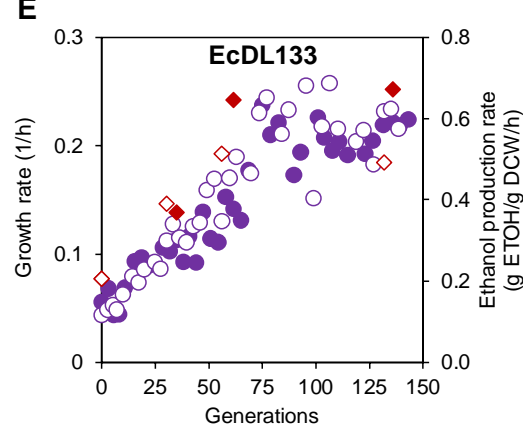

C

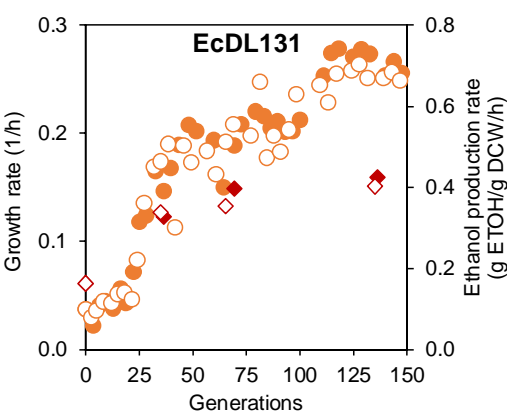

$\mathbf{F}$

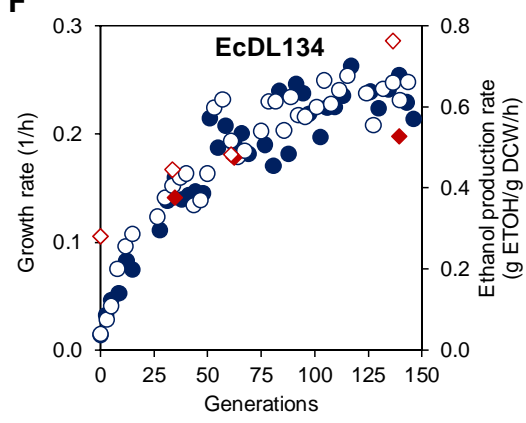

Isolation of individual evolved colonies

for i) irreversibility test

ii) extraction of evolved hosts and modules

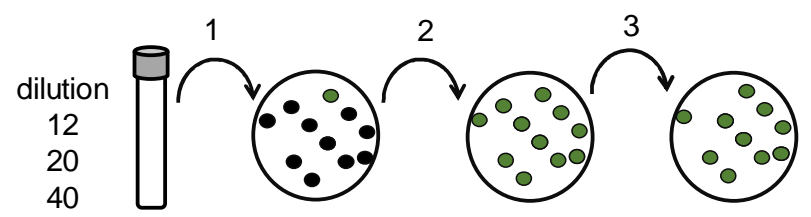

D

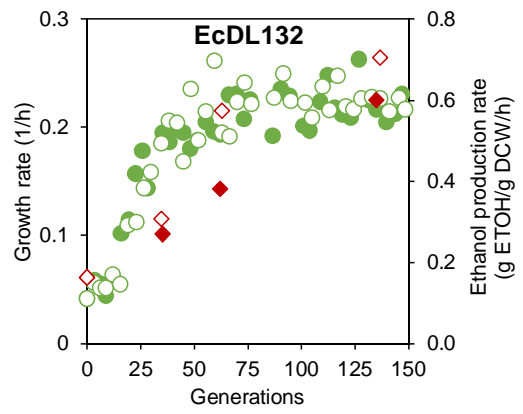

- Growth rate (replicate A)

o Growth rate (replicate B)

Ethanol production rate (replicate A)

$\diamond$ Ethanol production rate (replicate B) 
bioRxiv preprint doi: https://doi.org/10.1101/170910; this version posted July 31, 2017. The copyright holder for this preprint (which was not certified by peer review) is the author/funder, who has granted bioRxiv a license to display the preprint in perpetuity. It is made available under aCC-BY-NC-ND 4.0 International license.

\section{FIGURE 7}

745

A

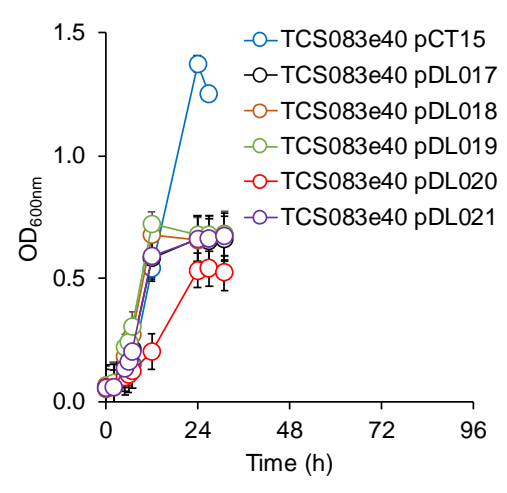

B

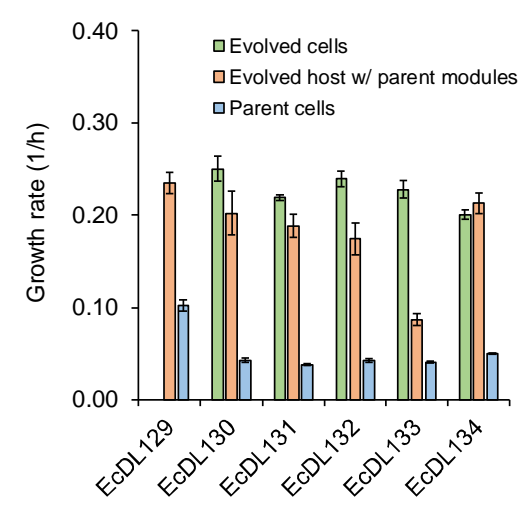

C

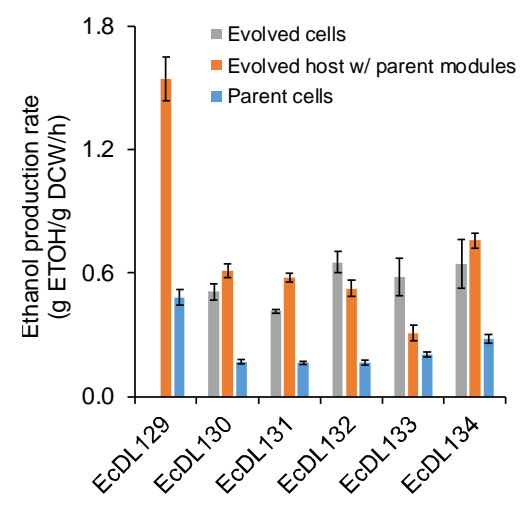

